\title{
Boron, Copper, and Zinc Affect the Productivity, Cup Quality, and Chemical Compounds in Coffee Beans
}

\author{
Junia Maria Clemente, ${ }^{1}$ Herminia Emilia Prieto Martinez $\left(\mathbb{D},{ }^{1}\right.$ Adriene Woods Pedrosa $(\mathbb{D}){ }^{2}$ \\ Yonara Poltronieri Neves, ${ }^{2}$ Paulo Roberto Cecon, ${ }^{3}$ and John Lonfover Jifon ${ }^{4}$ \\ ${ }^{1}$ Department of Plant Science, Universidade Federal de Viçosa, Avenue PH Rolfs, 36.570-000 Viçosa, MG, Brazil \\ ${ }^{2}$ Empresa de Pesquisa Agropecuária de Minas Gerais, EPAMIG Sudeste, Campus UFV-Cx. P. 216, 36.571-000 Viçosa, MG, Brazil \\ ${ }^{3}$ Department of Statistic, Universidade Federal de Viçosa, Avenue PH Rolfs, 36.570-000 Viçosa, MG, Brazil \\ ${ }^{4}$ Texas A\&M Agrilife Research and Extension Center, Environmental Plant Physiology, 2415 East Business 83, Weslaco, TX \\ 78596, USA
}

Correspondence should be addressed to Herminia Emilia Prieto Martinez; herminia@ufv.br

Received 8 December 2017; Accepted 8 April 2018; Published 14 May 2018

Academic Editor: Ana P. L. R. De Oliveira

Copyright (C) 2018 Junia Maria Clemente et al. This is an open access article distributed under the Creative Commons Attribution License, which permits unrestricted use, distribution, and reproduction in any medium, provided the original work is properly cited.

\begin{abstract}
Micronutrients perform specific and essential functions in plant metabolism, and their deficiency may lead to metabolic disturbances that affect coffee production and quality beverage. In Brazil, the $\mathrm{B}, \mathrm{Cu}$, and $\mathrm{Zn}$ are the main micronutrients, and these are provided by soil or foliar fertilization, frequently with low recovery efficiency. This work objected verifying the feasibility of supplying of $\mathrm{B}, \mathrm{Cu}$, and $\mathrm{Zn}$ via insertion of tablets in the orthotropic branch of Coffea arabica, as well as to evaluate the coffee plant response in terms of productivity and quality of the beverage. Adult plants received $\mathrm{B}, \mathrm{Cu}$, and $\mathrm{Zn}$, each micronutrient alone or combined with the other two, by foliar fertilization or by tablets inserted in the trunk base. The productivity, cupping quality, and some chemical indicators of beans quality were evaluated in two crop seasons. Boron, copper, and zinc supplied by foliar spray or solid injections in the trunk influenced the chemical composition and quality of the coffee beans, characterized by the cupping test and the levels of caffeine, trigonelline, sucrose, glucose, arabinose, mannose, 3-caffeoylquinic acid, 5-caffeoylquinic acid, polyphenol oxidase activity, and total phenolic compounds. Copper and zinc were equivalent in either form of supply regarding the production and quality of coffee.
\end{abstract}

\section{Introduction}

Brazil is the largest world producer of coffee. As a world leader in production and exportation, the country needs to attend market requirements, innovating and adopting technologies to produce good-quality types of coffee. The necessity of offering good coffees is rising due to an increase in coffee consumers looking for refined tastes and aromas, which are related to the chemical composition of the coffee beans. Flavor and aroma are the main criteria to evaluate beverage quality and also constitute the most important attributes for consuming coffee [1]. The cup test is the standard approach to evaluate the flavor and aroma of coffee; however, quite often, it is criticized because of its subjective nature [2]. Therefore, it is essential to explore alternative methods to accurately assess the chemical characteristics and the quality of beverage.

The production of bioactive compounds related to desirable flavor and aroma involves extremely complex chemical reactions, in which some mineral nutrients could have a key role. However, until now, little is known about the effect of the mineral nutrients $\mathrm{B}, \mathrm{Cu}$, and $\mathrm{Zn}$ on the production of chemical compounds that define the good quality of coffee. Most of the studies about mineral nutrition and coffee fertilization are focused on sources and doses of these nutrients, in order to optimize the productivity.

Boron deficiency is common in most of the Brazilian soils [3]. In coffee plants, its deficiency has been attributed to the natural loss of soil fertility, as well as to the wide use of highly demanding varieties. Boron deficiency in coffee plants 
can reduce the root system growth and cause the death of thin root tips and consequently the decrease in water and mineral absorption. In consequence of that, the plants become sensible to drought and less responsive to fertilizations. As B is highly immobile in the phloem sap [4], its supply via soil is desirable, although been supplied many times by foliar sprays, mixed with $\mathrm{Cu}$ and $\mathrm{Zn}$.

The $\mathrm{Cu}$ deficiency compromises the activity of several enzymes that catalyze oxidative reactions of several metabolic routes, especially the plastocyanin, superoxide dismutase, and polyphenoloxidase [5]. In the soil, $\mathrm{Cu}$ is strongly complexed by organic matter [6], so the common technique used for supplying $\mathrm{Cu}$ to coffee plants is through foliar sprays. The $\mathrm{Cu}$ deficiency can cause irreversible metabolic disturbances in coffee plants and possibly compromise the production of chemicals related to the beverage quality.

According to Fageria et al. [7], the lack of $\mathrm{Zn}$ impairs the world agriculture production, as well as the nutritional quality of grains. The main symptoms of $\mathrm{Zn}$ deficiency are related, in a still unclearly way, to disturbance in auxin metabolism $[5,8]$, which plays an essential role in the synthesis of tryptophan, an amino acid precursor of IAA [9]. The photosynthetic activity of coffee plants is hugely diminished under lack of Zn, given its importance on enzymes involved in carbon fixation [10]. Besides this, $\mathrm{Zn}$ regulates or makes part of the structure of several other enzymes involved in protein synthesis and in nitrogen metabolism $[5,11]$. In clayey acid soils, several reactions are responsible for the low $\mathrm{Zn}$ availability, which together with the low mobility of $\mathrm{Zn}$ in the coffee plant phloem drives to foliar fertilizations in such conditions $[12,13]$. Also, like other Brazilian coffee producer regions, Zona da Mata is a mountain region in which manually done foliar sprays are time-consuming and costly.

Coffees of superior quality are those that have chemical compounds responsible for the flavor and aroma such as caffeine, trigonelline, aldehydes, furans, ketones, sugars, proteins, amino acids, pyrroles, pyridines, pyrazines, oxazoles, carboxylic acids, fatty acids, and phenolic compounds in an equilibrated proportion to obtain good body, acidity, and smoothness of the beverage.

When in the presence of microorganisms or under anaerobic conditions, the sugars present in the coffee mucilage can be fermented and produce alcohols that may be broken down successively in acetic, lactic, propionic, and butyric acids. Pinto et al. [14] studying the quality of beans used to prepare espresso coffee observed that the low-quality ones, such as the types "rio" and "rioysh," presented higher acidity than the types "strictly soft" and "soft."

Electrical conductivity (EC) or the leached potassium (LK) has been used in researches as consistent indicators of cellular membrane integrity. They are accessory attributes used preferentially to differentiate beverages of the same class, having little adequacy as a unique mean of differentiation. Grains of bad quality commonly present higher EC and less organization and cellular structuring than the good ones, showing that EC is a strong indicator of membrane and cell wall damage [15].

Polyphenoloxidase (PPO) is a cupric enzyme linked to the cellular membranes, and as discussed in the literature, it is directly involved with the quality of the coffee beverage $[2,16,17]$. It is established that coffee beans that are strongly damaged or $\mathrm{Cu}$ deficient may have low PPO activity and low quality. Carvalho et al. [2] performed pioneering works, with physical and chemical evaluations of processed coffee beans previously classified as "strictly soft," "soft," "softish," "hard," "rioysh," and "rio," and verified that the coloration index and PPO allow the separation of beans with different coffee quality types.

Chlorogenic acids are the main nonvolatile phenolic compounds found in coffee beans and account for 6 to $12 \%$ of their dried mass [18]. They are formed by means of esterification of trans-cinnamic acids, such as caffeic acid, ferulic acid, and p-coumaric acid with quinic acids [19]. During the roast process, they are strongly degraded generating acids, lactones, and volatile compounds such as the phenil, guaiacol, and 4-vinyl guaiacol $[20,21]$, which contribute to the flavor and aroma of coffee, especially for the astringency of the beverage; the proanthocyanidins along with the polyphenols also provide an astringent flavor [22]. Within acceptable limits, chlorogenic acids have a positive effect on the beverage body.

Caffeine, commonly known as 1,3,7-trimethylxanthine, belongs to the methylxanthine class and gives bitterness to the coffee taste [19].

Trigonelline corresponds to around $1 \%$ of raw beans, and it is one of the precursors of aroma in coffee and undergoes degradation of up to $90 \%$ during roasting, forming mainly niacin, pyridines, and some pyrroles; the lower the trigonelline content in the beans, the lower the quality of the coffee beverage [23]. It is worth to highlight that the more drastic one is the roast process in which the lower levels of trigonelline will be found in the samples [24].

Production of secondary metabolism metabolites, such as polyphenols, caffeine, trigonelline, alcohols, and aldehydes, depends on the primary metabolism and its catabolic reactions that produce energy and the carbonic skeleton, such as sucrose. Therefore, if any factor affects photosynthates production during the fruits development, then it can also affect negatively the quality of beverage [25].

This work is aimed at evaluating the production of bioactive compounds and the quality of raw coffee beans harvested from plants fertilized with $\mathrm{B}, \mathrm{Cu}$, and $\mathrm{Zn}$ via foliar sprays or solid injections of salts in the trunk and correlates these variables with the nutritional status of the plants.

\section{Materials and Methods}

Three experiments were performed in July, in a field crop area of the Universidade Federal de Viçosa, Viçosa, Minas Gerais State, Brazil, using an adult orchard of Coffea arabica L. cv. Catuaí IAC-99 and have been conducted and evaluated during two crop seasons. The experimental field is located at $20^{\circ} 45$ south and $42^{\circ} 51$ west, at $541 \mathrm{~m}$ above the sea level. The soil of the experimental field is classified as a red-yellow latosol and the climate is classified as Cwa, according to the Köppen classification, with annual temperature and precipitation averages of $19.4^{\circ} \mathrm{C}$ and $1221.4 \mathrm{~mm}$, respectively. 
2.1. Treatments and Experimental Design. In the first experiment, the following treatments were performed to evaluate the boron effect: control without B supply, foliar sprays with boric acid at $0.4 \%$, injection of tablets containing B salts at the base of the trunk, injection of tablets containing $\mathrm{B}+\mathrm{Cu}$ salts at the base of the trunk, injection of tablets containing $\mathrm{B}+\mathrm{Zn}$ salts at the base of the trunk, and injection of tablets containing $\mathrm{B}+\mathrm{Cu}+\mathrm{Zn}$ salts at the base of the trunk.

The second experiment, to evaluate the copper effect, was performed in the same way as the first, receiving the following treatments: control without $\mathrm{Cu}$ supply, foliar sprays with copper sulphate at $0.4 \%$, injection of tablets containing $\mathrm{Cu}$ salts at the base of the trunk, injection of tablets containing $\mathrm{Cu}$ $+B$ salts at the base of the trunk, injection of tablets containing $\mathrm{Cu}+\mathrm{Zn}$ salts at the base of the trunk, and injection of tablets containing $\mathrm{Cu}+\mathrm{B}+\mathrm{Zn}$ salts at the base of the trunk.

The third experiment, to evaluate the zinc effect, was performed like the other two, receiving the following treatments: control without $\mathrm{Zn}$ supply, foliar sprays with zinc sulphate at $0.4 \%$, injection of tablets containing $\mathrm{Zn}$ salts at the base of the trunk, injection of tablets containing $\mathrm{Zn}+\mathrm{B}$ salts at the base of the trunk, injection of tablets containing $\mathrm{Zn}+\mathrm{Cu}$ salts at the base of the trunk, and injection of tablets containing $\mathrm{Zn}+\mathrm{B}+\mathrm{Cu}$ salts at the base of the trunk.

All the experiments were assigned as randomized blocks with 5 replications. Each plot was composed of 18 plants distributed in three rows $3 \mathrm{~m}$ apart and with $1 \mathrm{~m}$ between plants in a row. The four central plants constituted the useful plot. We worked with 30 total plots in each experiment.

The tablets of $\mathrm{B}$ and $\mathrm{Zn}$ were prepared at the Laboratory of Civil Engineering, Universidade Federal de Viçosa, using a hydraulic press with a force of 0.5 tons. The copper was supplied through capsules without any compression of the salts, due to the difficulty of these in forming compact mass with excipient agents. The tablets were implanted into the orthotropic branch of the coffee tree at $10 \mathrm{~cm}$ above the ground.

Considering that usually coffee foliar sprays are done with a volume of $400 \mathrm{~L} \cdot \mathrm{ha}^{-1}$ and that the orchard had 3333 plants per hectare, we used $120 \mathrm{~mL}$ of spraying solution per plant, totaling $480 \mathrm{~mL}$ per plot. All nutrients were sprayed by means of handheld sprayers with cone-filled nozzles, and we added $1 \mathrm{~mL} \cdot \mathrm{L}^{-1}$ of the adhesive adjuvant to the solution. Plastic curtains were placed between the rows to prevent drift.

In each crop season, three foliar sprays were applied between September and February. The liming and fertilization with nitrogen, phosphorus, and potassium were performed based on soil analysis, and the expected productivity, following the recommendations of [26].

In order to determine the nutritional status of the plants subjected to the different treatments, in the two crop seasons, coffee leaves were taken from the third or fourth nodes and counted from the apex to the base of plagiotropic branches, at a median height in the canopy and in the period between flowering and the first rapid expansion of the fruits. The leaves were washed in deionized water and dried in an oven with forced air at $70^{\circ} \mathrm{C}$, until constant weight.

Boron content was determined using the azomethine- $\mathrm{H}$ method after dry digestion of the plant material [27].
TABLE 1: Numerical scores for the coffee cupping test.

\begin{tabular}{lc}
\hline Taste & Nota \\
\hline Strictly soft (specialty coffee) & $\geq 87$ \\
Soft & $80-86$ \\
Softish & $74-79$ \\
Hard & $\leq 74$ \\
\hline
\end{tabular}

The content of $\mathrm{Cu}$ and $\mathrm{Zn}$ was determined by atomic absorption spectrophotometry [28] in the extract of the nitricperchloric acid digestion [29].

\subsection{Evaluations}

2.2.1. Production. The harvesting of the four usable plants of the plot was carried out, when the plants had approximately 95\% coffee cherries. The coffee cherries were handpicked and dried on a bench in a greenhouse until achieving $11 \%$ moisture content. After drying, they were hulled and used for the chemical analysis.

2.2.2. Cupping Quality. The cupping test was performed by professional tasters, using the $\mathrm{CoE}$ (cup of excellence) method (Table 1). Each attribute (clean beverage, sweetness, acidity, body, taste, flavor, and reminiscent taste) received a score based on the taste intensity exhibited by the samples, according to the Brazilian official method plus the grades described by the SCAA method for specialty coffees [30].

2.2.3. Chemical Analysis of the Coffee Beans. Total sugars, nonreducing sugars, coloration index, total titratable acidity, $\mathrm{pH}$, electrical conductivity, and leached potassium were evaluated in beans harvested in the crop season 2010/2011. Coloration index, leached potassium, total titratable acidity, $\mathrm{pH}$, electrical conductivity, caffeine, trigonelline, total phenolic compounds, sucrose, glucose, mannose, arabinose, galactose, proanthocyanidin, 3-caffeoylquinic acid, 4-caffeoylquinic acid, 5-caffeoylquinic acid, and PPO activity were evaluated in beans harvested in the crop season 2011/2012 as described below. All the extractions and readings were performed in duplicates.

Total sugars and reducing sugars were extracted by the Lane-Enyon method as described by the Association of Official Analytical Chemists [31] and determined by the Somogyi technique, adjusted by Nelson [32]. The nonreducing sugars were determined by the difference between total and reducing sugars. The coloration index was determined by Singleton [33], adapted for coffee. The results of total sugar were expressed in percentage (\%) and the coloration index in DO $425 \mathrm{~nm}$, respectively.

Total titratable acidity and the $\mathrm{pH}$ were determined as described by the Association of Official Analytical Chemists [31]. Already, electrical conductivity was determined according to the method described by Loeffler et al. [34], and the leached potassium was determined using a flame photometer, as described by Prete [35]. The results of total titratable acidity, electrical conductivity, and leached potassium were expressed 
TABle 2: Contents of $\mathrm{B}, \mathrm{Cu}$, and $\mathrm{Zn}\left(\mathrm{mg} \cdot \mathrm{kg}^{-1}\right)$ of index leaves of coffee plants that received $\mathrm{B}, \mathrm{Cu}$, and $\mathrm{Zn}$ as solid injections or foliar sprays (FSs).

\begin{tabular}{|c|c|c|}
\hline Crop season & $2010 / 2011$ & $2011 / 2012$ \\
\hline \multicolumn{3}{|l|}{ Boron } \\
\hline WB & $24.08^{*}$ & 27.46 \\
\hline FS (control) & $35.04^{+}$ & 30.35 \\
\hline B & $35.51^{+}$ & $50.41^{*,+}$ \\
\hline $\mathrm{B}+\mathrm{Cu}$ & $35.04^{+}$ & $64.65^{*++}$ \\
\hline $\mathrm{B}+\mathrm{Zn}$ & $33.26^{+}$ & $72.31^{*,+}$ \\
\hline $\mathrm{B}+\mathrm{Cu}+\mathrm{Zn}$ & $23.94^{*}$ & $78.64^{*,+}$ \\
\hline $\mathrm{CV}(\%)$ & 6.59 & 13.19 \\
\hline \multicolumn{3}{|l|}{ Copper } \\
\hline $\mathrm{WCu}$ & $9.64^{*}$ & $5.24^{*}$ \\
\hline FS (control) & $13.51^{+}$ & $13.14^{+}$ \\
\hline $\mathrm{Cu}$ & $17.06^{*,+}$ & $18.62^{*,+}$ \\
\hline $\mathrm{B}+\mathrm{Cu}$ & $14.94^{+}$ & $15.79^{*,+}$ \\
\hline $\mathrm{Cu}+\mathrm{Zn}$ & $18.96^{*,+}$ & $19.41^{*,+}$ \\
\hline $\mathrm{B}+\mathrm{Cu}+\mathrm{Zn}$ & $16.46^{*,+}$ & $16.52^{*,+}$ \\
\hline $\mathrm{CV}(\%)$ & 8.25 & 6.15 \\
\hline \multicolumn{3}{|l|}{ Zinc } \\
\hline WZn & $6.5^{*}$ & $4.68^{*}$ \\
\hline FS (control) & $10.06^{+}$ & $7.42^{+}$ \\
\hline $\mathrm{Zn}$ & $10.85^{+}$ & $11.58^{*,+}$ \\
\hline $\mathrm{B}+\mathrm{Zn}$ & $10.63^{+}$ & $10.89^{*,+}$ \\
\hline $\mathrm{Cu}+\mathrm{Zn}$ & $11.75^{*,+}$ & $13.66^{*,+}$ \\
\hline $\mathrm{B}+\mathrm{Cu}+\mathrm{Zn}$ & $9.85^{+}$ & $9.98^{*,+}$ \\
\hline CV (\%) & 6.25 & 16.31 \\
\hline
\end{tabular}

$\mathrm{WB}, \mathrm{WCu}$, and $\mathrm{WZn}$ : control treatments, without application of $\mathrm{B}, \mathrm{Cu}$, and $\mathrm{Zn}$, respectively; FS: foliar spray with boric acid, copper sulphate, and zinc sulphate (0.4\%); B: trunk injection of tablets containing B salts; Cu: trunk injection of tablets containing $\mathrm{Cu}$ salts; $\mathrm{Zn}$ : trunk injection of tablets containing $\mathrm{Zn}$ salts; $\mathrm{B}+\mathrm{Cu}$ : trunk injection of tablets containing $\mathrm{B}$ and $\mathrm{Cu}$ salts; $\mathrm{B}+\mathrm{Zn}$ : trunk injection of tablets containing $\mathrm{B}$ and $\mathrm{Zn}$ salts; $\mathrm{Cu}+\mathrm{Zn}$ : trunk injection of tablets containing $\mathrm{Cu}$ and $\mathrm{Zn}$ salts; $\mathrm{B}+\mathrm{Cu}+\mathrm{Zn}$ : trunk injection of tablets containing $\mathrm{B}, \mathrm{Cu}$, and $\mathrm{Zn}$ salts; ${ }^{*}$ mean values are statistically different from those of the control treatment (FS) at the $10 \%$ significance level, according to Dunnett's test; ${ }^{+}$mean values are statistically different from those of the control treatment (WB-WCu-WZn) at the $10 \%$ significance level, according to Dunnett's test.

in $\mathrm{mL}$ of $\mathrm{NaOH} 100 \mathrm{~g}^{-1}$ of the sample, $\mu \mathrm{S} \cdot \mathrm{cm}^{-1} \cdot \mathrm{g}^{-1}$, and $\mathrm{g} \cdot \mathrm{kg}^{-1}$, respectively.

The polyphenoloxidase (PPO) activity was determined as described by Ponting and Joslyn [36], using the sample extract without DOPA as the blank, and the results were expressed in $\mathrm{U} / \mathrm{min} / \mathrm{g}$ of the sample. Chlorogenic acids were extracted according to Farah et al. [37] and Trugo and Macrae [18], and the results were expressed in percentage (\%).

Caffeine was determined according to the method described by Mazzafera et al. [38] with additional modifications as described by Vitorino et al. [39], the trigonelline was determined according to the method described by Vitorino et al. [39], and phenolic compounds were determined by the Folin-Denis method as described by the Association of Official Analytical Chemists [31]. The results were expressed in percentage (\%).

The proanthocyanidins were determined as described by Hagerman et al. [40], and sucrose, glucose, mannose, galactose, and arabinose were determined as described by Sluiter et al. [41]. The results were expressed in percentage (\%).
2.2.4. Statistics. Data were submitted to variance analysis, and the means were compared by Dunnett's test at $10 \%$ of probability in the program SAEG 9.1 [42]. The treatment without $\mathrm{B}, \mathrm{Cu}$, and $\mathrm{Zn}$ was considered as the first control because it is the control of all treatments, and the sprayed treatment was considered as the second control because it is the usual form to supply $\mathrm{B}, \mathrm{Cu}$, and $\mathrm{Zn}$ to coffee plants.

\section{Results and Discussion}

3.1. Boron Content in Index Leaves. In the crop season $2010 / 2011$, the index leaves of the coffee plants that received $\mathrm{B}$ as foliar spray or solid injections with $\mathrm{B}, \mathrm{B}+\mathrm{Cu}$, or $\mathrm{B}+\mathrm{Zn}$ presented higher contents of $B$ than the control treatment without boron (WB). For this same crop season, the experiments evaluating tablets of $\mathrm{Cu}$ and $\mathrm{Zn}$ behaved the same way compared to the control treatments without $\mathrm{Cu}$ and without $\mathrm{Zn}$ (WCu-WZn; Table 2).

The content of $\mathrm{B}$ in the leaves of the treatments with $\mathrm{B}$, $\mathrm{B}+\mathrm{Zn}$, and $\mathrm{B}+\mathrm{Cu}$ was statistically similar to that in the sprayed control treatment, and the treatment with $\mathrm{B}+\mathrm{Cu}+\mathrm{Zn}$ was statistically lower in the first crop season (Table 2).

The content of $\mathrm{Cu}$ of the treatments with $\mathrm{Cu}, \mathrm{Cu}+\mathrm{Zn}$, and $\mathrm{B}+\mathrm{Cu}+\mathrm{Zn}$ was statistically higher than that observed in the sprayed control, suggesting fast release of the nutrient in the treatments that received $\mathrm{Cu}$ as solid injections. For the $\mathrm{Zn}$ content in leaves, only the $\mathrm{Cu}+\mathrm{Zn}$ treatment was significantly higher than the sprayed control (Table 2).

Considering the sufficiency ranges of 29 to $52 \mathrm{mg} \cdot \mathrm{kg}^{-1}$ for $\mathrm{B}, 13$ to $29 \mathrm{mg} \cdot \mathrm{kg}^{-1}$ for $\mathrm{Cu}$, and 6 to $12 \mathrm{mg} \cdot \mathrm{kg}^{-1}$ for $\mathrm{Zn}$ as determined by Martinez et al. [43] for the region of Viçosa, only the plants of the control treatment $(\mathrm{WB}-\mathrm{WCu})$ were deficient in $\mathrm{B}$ and $\mathrm{Cu}$ and the plants of the treatment with $\mathrm{B}+\mathrm{Cu}+\mathrm{Zn}$ were deficient in $\mathrm{B}$.

In the crop season 2011/2012, solid injections of $\mathrm{B}, \mathrm{Cu}$, and $\mathrm{Zn}$ in the trunk, pure or combined with two or three elements, resulted in higher contents of these nutrients in leaves than the treatments $\mathrm{WB}, \mathrm{WCu}$, and $\mathrm{WZn}$. In the case of $\mathrm{B}$, the concentrations attained could be considered toxic to the plants, while in comparison to the sprayed treatment, it can be noted that the content of all treatments that received solid injections of $\mathrm{B}, \mathrm{Cu}$, and $\mathrm{Zn}$ was significantly higher (Table 2).

In all treatments, except the treatments $\mathrm{WB}, \mathrm{WCu}$, and $\mathrm{WZn}$, the concentrations of $\mathrm{Cu}$ and $\mathrm{Zn}$ were considered adequate according to the method described by Martinez et al. [43]. The results suggest that both forms, in both crop seasons, were efficient to increase the contents of $\mathrm{B}, \mathrm{Cu}$, and $\mathrm{Zn}$ in index leaves of coffee plants, even with the necessity to review the composition and doses of B salts.

3.2. Production. In the first crop season, there were no statistically significant differences in coffee production. Plants in the B experiment yielded $3.59 \mathrm{~kg}$ of cherries per plant (2992 kg.ha ${ }^{-1}$ of processed coffee), while plants in the $\mathrm{Cu}$ and $\mathrm{Zn}$ experiments produced on average 3.61 and $3.54 \mathrm{~kg}$ of coffee cherries per plant $\left(3.005 \mathrm{~kg} \cdot \mathrm{ha}^{-1}\right.$ and $2947 \mathrm{~kg} \cdot \mathrm{ha}^{-1}$ of processed coffee, resp.). This result could be 
TABLE 3: Coffee cherry production of coffee plants submitted to the fertilization via solid salts injections in the trunk and foliar sprays with $\mathrm{B}, \mathrm{Cu}$, and $\mathrm{Zn}$.

\begin{tabular}{|c|c|c|}
\hline \multirow[t]{2}{*}{ Treatments } & \multicolumn{2}{|c|}{ Production } \\
\hline & $2010 / 2011$ & $2011 / 2012$ \\
\hline \multicolumn{3}{|l|}{ Boron } \\
\hline WB & 3.47 & 4.55 \\
\hline FS & 3.57 & 5.47 \\
\hline $\mathrm{B}$ & 3.83 & 4.30 \\
\hline $\mathrm{B}+\mathrm{Cu}$ & 3.74 & $6.15^{*,+}$ \\
\hline $\mathrm{B}+\mathrm{Zn}$ & 3.47 & $5.59^{*,+}$ \\
\hline $\mathrm{B}+\mathrm{Cu}+\mathrm{Zn}$ & 3.45 & 3.93 \\
\hline Means & 3.59 & 5.00 \\
\hline CV (\%) & 22.88 & 26.66 \\
\hline \multicolumn{3}{|l|}{ Copper } \\
\hline $\mathrm{WCu}$ & 3.47 & 4.55 \\
\hline FS & 3.57 & 5.47 \\
\hline $\mathrm{Cu}$ & 3.99 & 5.56 \\
\hline $\mathrm{B}+\mathrm{Cu}$ & 3.74 & $6.15^{*,+}$ \\
\hline $\mathrm{Cu}+\mathrm{Zn}$ & 3.42 & 5.15 \\
\hline $\mathrm{B}+\mathrm{Cu}+\mathrm{Zn}$ & 3.45 & 3.93 \\
\hline Means & 3.61 & 5.13 \\
\hline CV (\%) & 22.85 & 20.38 \\
\hline \multicolumn{3}{|l|}{ Zinc } \\
\hline WZn & 3.47 & 4.55 \\
\hline FS & 3.57 & 5.47 \\
\hline $\mathrm{Zn}$ & 3.83 & 5.24 \\
\hline $\mathrm{B}+\mathrm{Zn}$ & 3.47 & 5.59 \\
\hline $\mathrm{Cu}+\mathrm{Zn}$ & 3.42 & 5.15 \\
\hline $\mathrm{B}+\mathrm{Cu}+\mathrm{Zn}$ & 3.45 & 3.93 \\
\hline Means & 3.54 & 4.99 \\
\hline CV (\%) & 28.56 & 27.03 \\
\hline
\end{tabular}

$\mathrm{WB}, \mathrm{WCu}$, and $\mathrm{WZn}$ : control treatments, without application of $\mathrm{B}, \mathrm{Cu}$, and $\mathrm{Zn}$, respectively; FS: foliar spray with boric acid, copper sulphate, and zinc sulphate (0.4\%); B: trunk injection of tablets containing B salts; Cu: trunk injection of tablets containing $\mathrm{Cu}$ salts; $\mathrm{Zn}$ : trunk injection of tablets containing $\mathrm{Zn}$ salts; $\mathrm{B}+\mathrm{Cu}$ : trunk injection of tablets containing $\mathrm{B}$ and $\mathrm{Cu}$ salts; $\mathrm{B}+\mathrm{Zn}$ : trunk injection of tablets containing $\mathrm{B}$ and $\mathrm{Zn}$ salts; $\mathrm{Cu}+\mathrm{Zn}$ : trunk injection of tablets containing $\mathrm{Cu}$ and $\mathrm{Zn}$ salts, $\mathrm{B}+\mathrm{Cu}+\mathrm{Zn}$ : trunk injection of tablets containing $\mathrm{B}, \mathrm{Cu}$, and $\mathrm{Zn}$ salts; ${ }^{*}$ mean values are statistically different from those of the control treatment (FS) at the $10 \%$ significance level, according to Dunnett's test; ${ }^{+}$mean values are statistically different from those of the control treatment (WB-WCu-WZn) at the $10 \%$ significance level, according to Dunnett's test.

due to the fact that fruits are produced in nodes formed in the previous growing season; therefore, nodes in which the fruiting occurred were already formed prior to treatment applications in this study (Table 3).

In the crop season 2011/2012, there was a significant difference in coffee production among the treatments at $10.9 \%$ of probability (Table 3), with the productions of the treatments containing $\mathrm{B}(\mathrm{B}+\mathrm{Cu}$ and $\mathrm{B}+\mathrm{Zn}) 35.01 \%$ and $22.82 \%$ greater than that in the treatment WB. Such differences correspond to $1328 \mathrm{~kg} \cdot \mathrm{ha}^{-1}$ and $866 \mathrm{~kg} \cdot \mathrm{ha}^{-1}$ of processed coffee, respectively, even with the index leaves presenting excessive concentrations of the nutrient (Tables 2 and 3).

For the $\mathrm{Cu}$ experiment, the production of the treatment with $\mathrm{B}+\mathrm{Cu}$ was statistically different, considering the treatment without $\mathrm{Cu}$ or the sprayed treatment as controls (Table 3). These results suggest that tablets containing $\mathrm{B}+\mathrm{Cu}$ salts supplied $\mathrm{Cu}$ in adequate amounts, but the most interesting finding was the good combination with $\mathrm{B}$ and $\mathrm{Cu}$ in the same tablet, since the treatments containing only $\mathrm{Cu}$, $\mathrm{Cu}+\mathrm{Zn}$, and $\mathrm{B}+\mathrm{Cu}+\mathrm{Zn}$ and the sprayed treatment were statistically equal compared to the treatment $\mathrm{WCu}$. Later, maybe the plants were slightly sensitive to high concentrations of $\mathrm{Cu}$, as can be concluded taking into account the $\mathrm{Cu}$ content in the index leaves.

For the $\mathrm{Zn}$ experiment, there was no significant effect of $\mathrm{Zn}$ on production, in the two crop seasons, even with the variations in the content of $\mathrm{Zn}$ in index leaves, with the mean values of the production in the second crop year being 4.99 (4157 kg.ha ${ }^{-1}$ of processed coffee) (Table 3).

The high level of probability used can be considered acceptable for coffee experiments conducted in commercial orchards because the experimental conditions are very heterogeneous and each coffee plant of the plant population has great variability.

According to Brown and Shelp [44], the B moves in the form of complexes with polyols (sugar-alcohol), and coffee has a large amount of mannitol, but there is little information on the distribution of these polyols. Brown and $\mathrm{Hu}$ [45] observed that, in coffee plants, the B is immobile in phloem because of the low capacity of forming stable complexes with sucrose; therefore, the foliar sprays correct the deficiency only in the leaves that received the fertilizers, and the leaves that grow after fertilizers application will present low $\mathrm{B}$ concentrations, demanding a greater number of applications.

Santinato et al. [46] working with high doses of boric acid applied in the soil observed that, despite the plant did not present toxicity symptoms, excessive doses caused reduction of $600 \mathrm{~kg} \cdot \mathrm{ha}^{-1}$ of processed coffee.

Positive correlations between B availability in soil and the harvest index were found by Lima Filho and Malavolta [47] for Coffea arabica cv. Catuaí Amarelo. They have observed a great correlation among the harvest index and $\mathrm{B}$ content in leaves, branches length, and number of leaves and branches and low correlation among the harvest index and dry matter of the roots, stem, branches, and leaves. These variables are important for coffee production because, according to Rena and Maestri [48], the vertical growth of coffee plant determines the formation of nodes, and from buds of these nodes emerge plagiotropic branches, in which nodes will develop leaves and inflorescences. Therefore, the flowering depends on the branches growth, the number of nodes, and numbers of leaves, since it is to verify that many nodes without leaves do not flower.

According to Santinato et al. [49], 6 to 12 applications per year with solutions at the concentration of $0.25 \%$ organic boron $(10 \% \mathrm{~B})$ not coinciding with the flowering provided high productivity and maintained good correlation between $\mathrm{B}$ content in leaves and production, although there was no significant difference between the treatments regarding the $\mathrm{B}$ content in leaves. Barros et al. [50] observed that boric acid application at $0.3 \%$ twice a year resulted in productions only $8 \%$ higher than the control treatment without B application. On the other hand, Lima Filho and Malavolta [47] and Barros et al. [50] reported that the increase in B 
concentration not always provides an increase in coffee productivity.

According to Andrade [51], in adult coffee plants receiving sprays containing $\mathrm{Cu}$, high $\mathrm{Cu}$ content present in leaf did not reduce production possibly because $\mathrm{Cu}$ is located on the leaf surface or even because the element remains largely in the cuticle not reaching the cytoplasm. Loneragan [52] states that $\mathrm{Cu}$ movement into the plants depends on its concentration. During the initial stages of growth, $\mathrm{Cu}$ in excess causes reduction on the branching, thickening, and abnormal coloration of rootlets [53].

Regarding Zn in a field experiment, Guimarães et al. [54] observed an increase of 60 to $360 \mathrm{~kg} \cdot \mathrm{ha}^{-1}$ of processed coffee with $\mathrm{Zn}$ supplementation by foliar spray, followed by the increase in the concentration of $\mathrm{Zn}$ from 8 to $21 \mathrm{mg} \cdot \mathrm{kg}^{-1}$ in index leaves. In turn, Lima Filho and Malavolta [55] proved the positive interaction between B and Zn studying the dry matter production in seedlings of coffee varieties, and when the nutrients were supplied together, the dry matter production was $21 \%$ higher.

In a field experiment performed in the same conditions of that of the experiment reported here, Martinez et al. [56] studied the effect of $\mathrm{Zn}$ on the production and on some quality attributes of coffee beans and did not observe effect of the nutrient on the production; however, there was an effect of $\mathrm{Zn}$ on beans size. Moreover, plants supplemented with $\mathrm{Zn}$ had the highest percentage of exportable grains, retained in the sieves 17 and 18. Still according to these authors, there was no significant effect of $\mathrm{Zn}$ on the cup quality of coffee beans; however, the score related to the cup quality of the beans harvested from plants that did not receive $\mathrm{Zn}$ was 60 , while in the beans harvested from plants that received $\mathrm{Zn}$, it was 72.5 .

In the same orchard, Neves et al. [57] studied the effect of Zn, supplied by trunk injection and foliar sprays, on the production and on some attributes of quality. The cumulative production of two crop seasons for treatments that received tablets of $\mathrm{Zn}$ inserted in the trunk and the treatment without $\mathrm{Zn}$ was 11,292 and $7810 \mathrm{~kg} \cdot \mathrm{ha}^{-1}$ of processed coffee, respectively. The difference among them was $3482 \mathrm{~kg} \cdot \mathrm{ha}^{-1}$, which corresponds at $30.9 \%$. Still according to the authors, the beans were classified as "hard" type, and there was no significant effect of $\mathrm{Zn}$ on coffee bean quality evaluated by the cup test.

3.3. Cupping Quality. There was no significant effect of B on the cupping test in both years, with the overall mean grades of 83.73 and 80.4 in the respective assessed years; in general, the coffee beans were classified as "soft" (Table 4).

Comparing tablets with the treatment $\mathrm{WCu}$ and the sprayed treatment, only the treatment containing $\mathrm{Cu}$ $+\mathrm{Zn}$ had statistically low scores in the crop season $2011 / 2012$, evidencing the effect of the way of $\mathrm{Cu}$ supply and the effect of the nutrient on the cupping quality. As previously reported, the index leaves of the plants subjected to this treatment had slightly high $\mathrm{Cu}$ content. In case of $\mathrm{Cu}$ and $\mathrm{Zn}$ tending to the excess quantity, there is a negative interaction with other cationic micronutrients
TABle 4: Cupping test of coffee beans harvested from plants submitted to fertilization via solid salts injections and foliar spray with $\mathrm{B}, \mathrm{Cu}$, and $\mathrm{Zn}$.

\begin{tabular}{|c|c|c|}
\hline Treatments & $2010 / 2011$ & $2011 / 2012$ \\
\hline \multicolumn{3}{|l|}{ Cupping test } \\
\hline \multicolumn{3}{|l|}{ Boron } \\
\hline WB & 82.4 & 82.7 \\
\hline FS & 84.8 & 83.9 \\
\hline B & 84.4 & 72.8 \\
\hline $\mathrm{B}+\mathrm{Cu}$ & 83.4 & 83.25 \\
\hline $\mathrm{B}+\mathrm{Zn}$ & 83.6 & 79.35 \\
\hline $\mathrm{B}+\mathrm{Cu}+\mathrm{Zn}$ & 83.8 & 80.4 \\
\hline CV (\%) & 3.76 & 8.20 \\
\hline \multicolumn{3}{|l|}{ Copper } \\
\hline $\mathrm{WCu}$ & 82.4 & 82.7 \\
\hline FS & 84.8 & 83.9 \\
\hline $\mathrm{Cu}$ & 85.0 & 81.5 \\
\hline $\mathrm{B}+\mathrm{Cu}$ & 83.4 & 83.25 \\
\hline $\mathrm{Cu}+\mathrm{Zn}$ & 82.0 & $74.6^{*++}$ \\
\hline $\mathrm{B}+\mathrm{Cu}+\mathrm{Zn}$ & 83.8 & 80.4 \\
\hline CV (\%) & 4.27 & 5.81 \\
\hline \multicolumn{3}{|l|}{ Zinc } \\
\hline WZn & 82.4 & 82.7 \\
\hline FS & 84.8 & 83.9 \\
\hline $\mathrm{Zn}$ & 84.2 & 78.9 \\
\hline $\mathrm{B}+\mathrm{Zn}$ & 83.6 & 79.35 \\
\hline $\mathrm{Cu}+\mathrm{Zn}$ & 82.0 & 74.6 \\
\hline $\mathrm{B}+\mathrm{Cu}+\mathrm{Zn}$ & 83.8 & 80.4 \\
\hline CV (\%) & 4.34 & 10.17 \\
\hline
\end{tabular}

$\mathrm{WB}, \mathrm{WCu}$, and $\mathrm{WZn}$ : control treatments, without application of $\mathrm{B}, \mathrm{Cu}$, and $\mathrm{Zn}$, respectively; FS: foliar spray with boric acid, copper sulphate, and zinc sulphate $(0.4 \%)$; B: trunk injection of tablets containing B salts; $\mathrm{Cu}$ : trunk injection of tablets containing $\mathrm{Cu}$ salts; $\mathrm{Zn}$ : trunk injection of tablets containing $\mathrm{Zn}$ salts; $\mathrm{B}+\mathrm{Cu}$ : trunk injection of tablets containing $\mathrm{B}$ and $\mathrm{Cu}$ salts; $\mathrm{B}+\mathrm{Zn}$ : trunk injection of tablets containing $\mathrm{B}$ and $\mathrm{Zn}$ salts; $\mathrm{Cu}+\mathrm{Zn}$ : trunk injection of tablets containing $\mathrm{Cu}$ and $\mathrm{Zn}$ salts; $\mathrm{B}+\mathrm{Cu}+\mathrm{Zn}$ : trunk injection of tablets containing $\mathrm{B}, \mathrm{Cu}$, and $\mathrm{Zn}$ salts; * mean values are statistically different from those of the control treatment (FS) at the $10 \%$ significance level, according to Dunnett's test; ${ }^{+}$mean values are statistically different from those of the control treatment (WB-WCu-WZn) at the $10 \%$ significance level, according to Dunnett's test.

that when in appropriate concentrations certainly would influence positively the route of production of compounds associated with desirable flavors and aromas (Tables 2 and 4 ).

There was no effect of $\mathrm{Zn}$ on the cupping test, reaching scores of 83.46 and 79.97 in the two crop seasons, respectively, and the beans would be classified as "soft" (Table 4). In spite of the fact that the precision and validity of the cupping are much discussed because of its subjective nature and the limitation of tasters abilities, this result points out to the major importance of the postharvest procedures than the mineral nutrition of the plant on coffee quality.

3.4. Electrical Conductivity, Leached Potassium, and Coloration Index in the Crop Season 2010/2011. In the first crop season, there was no effect of $\mathrm{B}, \mathrm{Cu}$, and $\mathrm{Zn}$ supplied as tablets on CI, TTA, pH, EC, KL, TS, and RS of the beans 
TABle 5: Coloration index (CI, DO $425 \mathrm{~nm}$ ), total titratable acidity (TTA, $\mathrm{mL} \mathrm{NaOH} 100 \mathrm{~g}^{-1}$ ), $\mathrm{pH}$, electrical conductivity (EC, $\left.\mu \mathrm{S} \cdot \mathrm{cm}^{-1} \cdot \mathrm{g}^{-1}\right)$, leached potassium (KL, $\mathrm{g} \cdot \mathrm{kg}^{-1}$ ), total sugars (TS, \%), and reducing sugars (RS, \%) in coffee beans of Coffea arabica treated with different forms of $\mathrm{B}, \mathrm{Cu}$, and $\mathrm{Zn}$ supply, in the crop season 2010/2011.

\begin{tabular}{|c|c|c|c|c|c|c|c|}
\hline \multicolumn{8}{|c|}{ Crop season $2010 / 2011$} \\
\hline \multicolumn{8}{|l|}{ Boron } \\
\hline Treatments & $\mathrm{CI}$ & TTA & $\mathrm{pH}$ & EC & $\mathrm{KL}$ & TS & RS \\
\hline WB & 0.81 & 11.2 & 5.61 & 41.39 & 1.29 & 11.73 & 0.216 \\
\hline FS & 0.89 & 10.4 & 5.60 & 42.71 & 1.40 & 11.41 & 0.197 \\
\hline B & 0.84 & 10.0 & 5.60 & 41.36 & 1.30 & 11.63 & 0.212 \\
\hline $\mathrm{B}+\mathrm{Cu}$ & 0.93 & 10.4 & 5.58 & 41.84 & 1.29 & 12.09 & 0.199 \\
\hline $\mathrm{B}+\mathrm{Zn}$ & 0.91 & 10.8 & 5.50 & 41.09 & 1.23 & 9.70 & 0.279 \\
\hline $\mathrm{B}+\mathrm{Cu}$ & 0.93 & 11.2 & 5.61 & 38.87 & 1.23 & 11.28 & 0.264 \\
\hline $\mathrm{CV}$ & 12.03 & 20.05 & 1.35 & 14.26 & 12.67 & 13.91 & 34.39 \\
\hline \multicolumn{8}{|l|}{ Copper } \\
\hline Treatments & $\mathrm{CI}$ & TTA & $\mathrm{pH}$ & EC & KL & TS & RS \\
\hline $\mathrm{WCu}$ & 0.81 & 11.2 & 5.61 & 41.39 & 1.29 & 11.73 & 0.216 \\
\hline FS & 0.89 & 10.4 & 5.61 & 42.71 & 1.40 & 11.41 & 0.197 \\
\hline $\mathrm{Cu}$ & 0.87 & 10.4 & 5.60 & 41.98 & 1.36 & 11 & 0.221 \\
\hline $\mathrm{Cu}$ & 0.93 & 10.4 & 5.58 & 41.84 & 1.29 & 12.09 & 0.199 \\
\hline $\mathrm{Cu}$ & 0.8 & 11. & 5.58 & 38 & 1 & 12.20 & 0.211 \\
\hline $\mathrm{B}+$ & 0.93 & 11.2 & 5.61 & 38.87 & 1.23 & 11.28 & 0.264 \\
\hline CV (\%) & 10.76 & 24.48 & 0.75 & 13.8 & 13.67 & 14.16 & 20.22 \\
\hline \multicolumn{8}{|l|}{ Zinc } \\
\hline Treatr & C & $11 \mathrm{~A}$ & PII & & & & RS \\
\hline WZn & 0.80 & 11.2 & 5.61 & 41.39 & 1.29 & 11.73 & 0.216 \\
\hline FS & 0.89 & 10.4 & 5.60 & 42.71 & 1.40 & 11.41 & 0.197 \\
\hline $\mathrm{Zn}$ & 0.90 & 11.2 & 5.62 & 41.09 & 1.32 & 12.13 & 0.209 \\
\hline $\mathrm{Zn}+\mathrm{B}$ & 0.91 & 10.8 & 5.50 & 41.09 & 1.23 & 9.70 & 0.279 \\
\hline $\mathrm{Zn}+\mathrm{Cu}$ & 0.88 & 11.6 & 5.58 & 38.14 & 1.18 & 12.20 & 0.211 \\
\hline $\mathrm{B}+\mathrm{Cu}+$ & 0.93 & 11.2 & 5.61 & 38.87 & 1.23 & 11.28 & 0.264 \\
\hline CV (\%) & 11.06 & 17.27 & 1.45 & 16.7 & 14.13 & 17.24 & 35.64 \\
\hline
\end{tabular}

$\mathrm{WB}, \mathrm{WCu}$, and $\mathrm{WZn}$ : control treatments, without application of $\mathrm{B}, \mathrm{Cu}$, and $\mathrm{Zn}$, respectively; FS: foliar spray with boric acid, copper sulphate, and zinc sulphate $(0.4 \%)$; B: trunk injection of tablets containing B salts; $\mathrm{Cu}$ : trunk injection of tablets containing $\mathrm{Cu}$ salts; $\mathrm{Zn}$ : trunk injection of tablets containing $\mathrm{Zn}$ salts; B + Cu: trunk injection of tablets containing B and $\mathrm{Cu}$ salts; $\mathrm{B}+\mathrm{Zn}$ : trunk injection of tablets containing $\mathrm{B}$ and $\mathrm{Zn}$ salts; $\mathrm{Cu}+\mathrm{Zn}$ : trunk injection of tablets containing $\mathrm{Cu}$ and $\mathrm{Zn}$ salts; $\mathrm{B}+\mathrm{Cu}+\mathrm{Zn}$ : trunk injection of tablets containing $\mathrm{B}, \mathrm{Cu}$, and $\mathrm{Zn}$ salts; * mean values are statistically different from those of the control treatment (FS) at the $10 \%$ significance level, according to Dunnett's test; ${ }^{+}$mean values are statistically different from those of the control treatment (WB-WCu-WZn) at the $10 \%$ significance level, according to Dunnett's test.

compared to the treatments $\mathrm{WB}, \mathrm{WCu}$, and $\mathrm{WZn}$ or the sprayed treatments as controls (Table 5).

In the second crop season, there was no effect of $B$ on the TTA, EC, and KL. Only the treatments with $\mathrm{B}+\mathrm{Cu}+\mathrm{Zn}$ and $\mathrm{B}+\mathrm{Cu}$ differed from the sprayed treatment but did not differ from the treatment without $\mathrm{B}$, indicating the effect of the way of B supply on this variable but not the effect of the nutrient (Table 6).

There was no effect of $\mathrm{Cu}$ on TTA, $\mathrm{pH}, \mathrm{EC}$, and $\mathrm{KL}$. The treatments that received $\mathrm{Cu}, \mathrm{Cu}+\mathrm{B}, \mathrm{Cu}+\mathrm{Zn}$, and $\mathrm{B}+\mathrm{Cu}$ $+\mathrm{Zn}$ via solid injections differed from the sprayed treatment, and considering the treatment $\mathrm{WCu}$ as control, only the sprayed treatment was different, indicating the effect of $\mathrm{Cu}$ and the way of $\mathrm{Cu}$ supply on $\mathrm{CI}$ (Table 6).
TABle 6: Coloration index (CI, DO $425 \mathrm{~nm}$ ), total titratable acidity (TTA, mL of $\mathrm{NaOH} 100 \mathrm{~g}^{-1}$ ), $\mathrm{pH}$, electrical conductivity (EC, $\left.\mu \mathrm{S} \cdot \mathrm{cm}^{-1} \cdot \mathrm{g}^{-1}\right)$, and leached potassium (KL, $\mathrm{g} \cdot \mathrm{kg}^{-1}$ ) of coffee beans of Coffea arabica treated with different forms of $\mathrm{B}, \mathrm{Cu}$, and $\mathrm{Zn}$ supply, in the crop season $2011 / 2012$.

\begin{tabular}{|c|c|c|c|c|c|}
\hline \multicolumn{6}{|c|}{ Crop season 2011/2012 } \\
\hline \multicolumn{6}{|l|}{ Boron } \\
\hline Treatments & $\mathrm{CI}$ & TTA & $\mathrm{pH}$ & EC & $\mathrm{KL}$ \\
\hline WB & 0.51 & 49.41 & 5.72 & 57.52 & 2.15 \\
\hline FS (control) & 0.76 & 48.42 & $5.63^{+}$ & 50.18 & 2.01 \\
\hline $\mathrm{B}$ & 0.74 & 41.50 & $5.63^{+}$ & 56.77 & 2.27 \\
\hline $\mathrm{B}+\mathrm{Cu}$ & $0.37^{*}$ & 40.52 & 5.68 & 60.98 & 2.05 \\
\hline$B+Z n$ & 0.66 & 45.46 & 5.69 & 58.83 & 1.86 \\
\hline $\mathrm{B}+\mathrm{Cu}+\mathrm{Zn}$ & $0.41^{*}$ & 50.40 & $5.74^{*}$ & 59.27 & 2.02 \\
\hline CV (\%) & 31.89 & 31.12 & 0.86 & 13.47 & 14.28 \\
\hline \multicolumn{6}{|l|}{ Copper } \\
\hline $\mathrm{WCu}$ & 0.51 & 49.41 & 5.72 & 57.52 & 2.15 \\
\hline FS (control) & $0.76^{+}$ & 48.42 & 5.63 & 50.18 & 2.01 \\
\hline $\mathrm{Cu}$ & $0.50^{*}$ & 59.29 & 5.64 & 56.92 & 1.93 \\
\hline $\mathrm{Cu}+\mathrm{B}$ & $0.37^{*}$ & 40.52 & 5.68 & 60.98 & 2.05 \\
\hline $\mathrm{Cu}+\mathrm{Zn}$ & $0.50^{*}$ & 48.42 & 5.70 & 62.73 & 2.12 \\
\hline $\mathrm{B}+\mathrm{Cu}+\mathrm{Zn}$ & $0.41^{*}$ & 50.40 & 5.74 & 59.27 & 2.02 \\
\hline CV (\%) & 29.25 & 31.61 & 1.26 & 12.79 & 14.15 \\
\hline \multicolumn{6}{|l|}{ Zinc } \\
\hline WZn & 0.51 & 49.41 & 5.71 & 57.52 & 2.15 \\
\hline FS (control) & 0.76 & 48.42 & 5.63 & 50.18 & 2.01 \\
\hline $\mathrm{Zn}$ & 0.52 & 42.49 & 5.65 & 58.29 & 2.36 \\
\hline $\mathrm{Zn}+\mathrm{B}$ & 0.66 & 45.46 & 5.69 & 58.83 & 1.86 \\
\hline $\mathrm{Zn}+\mathrm{Cu}$ & 0.50 & 48.42 & 5.70 & 62.73 & 2.12 \\
\hline $\mathrm{B}+\mathrm{Cu}+\mathrm{Zn}$ & 0.41 & 50.40 & 5.74 & 59.27 & 2.02 \\
\hline CV (\%) & 31.29 & 30.14 & 1.17 & 15.86 & 15.91 \\
\hline
\end{tabular}

$\mathrm{WB}, \mathrm{WCu}$, and $\mathrm{WZn}$ : control treatments, without application of $\mathrm{B}, \mathrm{Cu}$, and $\mathrm{Zn}$, respectively; FS; foliar spray with boric acid, copper sulphate, and zinc sulphate (0.4\%); B: trunk injection of tablets containing B salts; Cu: trunk injection of tablets containing $\mathrm{Cu}$ salts; $\mathrm{Zn}$ : trunk injection of tablets containing $\mathrm{Zn}$ salts; $\mathrm{B}+\mathrm{Cu}$ : trunk injection of tablets containing $\mathrm{B}$ and $\mathrm{Cu}$ salts; $\mathrm{B}+\mathrm{Zn}$ : trunk injection of tablets containing $\mathrm{B}$ and $\mathrm{Zn}$ salts; $\mathrm{Cu}+\mathrm{Zn}$ : trunk injection of tablets containing $\mathrm{Cu}$ and $\mathrm{Zn}$ salts; $\mathrm{B}+\mathrm{Cu}+\mathrm{Zn}$ : trunk injection of tablets containing $\mathrm{B}, \mathrm{Cu}$, and $\mathrm{Zn}$ salts; ${ }^{*}$ mean values are statistically different from those of the control treatment (FS) at the $10 \%$ significance level, according to Dunnett's test; ${ }^{+}$mean values are statistically different from those of the control treatment (WB-WCu-WZn) at the $10 \%$ significance level, according to Dunnett's test.

Zinc did not influence the CI, TTA, pH, EC, and $\mathrm{KL}$ in this crop season (Table 6).

According to Carvalho et al. [2], the coloration index allows separation of different types of coffees, such as "rioysh" and "rio," that are not acceptable drink with coloration indexes lower than 0.650 DO $425 \mathrm{~nm}$. For those classified as "hard" (acceptable), "soft," "softish" (fine), and "strictly soft" (extra fine), the coloration indexes would be equal or greater than 0.650 DO $425 \mathrm{~nm}$.

Results obtained during the second crop season of evaluation suggest that the coloration index may not be a good indicator of quality as assessed by the cupping test. Although color indices were very similar, cup quality scores for beans from trees with spray treatments were $15.24 \%$ higher than those with trunk insertion of B tablets (Tables 4 and 6).

The coloration index of the sprayed treatment is in agreement with that reported by [2] in which the coffees of 
best quality were darker and the dark coloration attributed to the formation of essential compounds to develop desirable flavors and aromas (Table 6).

On the other hand, the treatments containing $\mathrm{B}+\mathrm{Cu}$ and $\mathrm{B}+\mathrm{Cu}+\mathrm{Zn}$ presented the coloration index quite low $(0.368$ and $0.411 \mathrm{DO} 425 \mathrm{~nm}$, resp.) and high cupping quality scores (83.25 and 80.4, resp.), being, in this case, classified as "softish," probably because of the positive effects of $\mathrm{Cu}$ and $\mathrm{Zn}$, contradicting the findings of Carvalho et al. [2]. Corrêa et al. [58] also reported that higher CI could be attributed to the occurrence of biochemical alterations and oxidative reactions caused by the dry conditions or inadequate storage.

Martinez et al. [56] studying Zn effect on the production and cupping quality of coffee did not observe $\mathrm{Zn}$ effect on the coloration index, with the mean values being $0.95 \mathrm{DO}$ $425 \mathrm{~nm}$, which is in agreement with the results found by Lima et al. [59] for good coffees and, also, with the means found in this work.

Cellular membrane damage and the subsequent loss of permeability control were proposed by Heydecker Vigour [60] and Harrington [61] as the early step in the seed deterioration process. According to Amorim [16], since the leached potassium is proportional to the loss of bean quality, it can be observed that the loss of membrane permeability caused damage in coffee beans.

Malta et al. [62] studying some attributes related to the quality of different coffee varieties noted that Catuaí Vermelho presented an electrical conductivity of $104 \mu \mathrm{S} \cdot \mathrm{cm}^{-1} \cdot \mathrm{g}^{-1}$, considerably higher than that reported in the present experiment, even for the treatments with no micronutrient supply.

Lima et al. [63] determined the electrical conductivity of beans subjected to $B$ doses and verified that both the absence and toxic concentrations of the nutrient are harmful to the quality of bean seeds, enhancing the electrical conductivity. Moreover, high physiological quality of bean seeds was obtained in a consortium with beans and castor beans, when supplied with adequate doses of B.

Evaluating the physiological quality of bean seeds over different doses of $\mathrm{Mn}$ and $\mathrm{Zn}$, Teixeira et al. [64] did not observe the effect of $\mathrm{Zn}$ on the electrical conductivity; however, adequate doses of $\mathrm{Mn}$ improve seed quality resulting in low electrical conductivity $\left(65.8 \mu \mathrm{Scm}^{-1} \cdot \mathrm{g}^{-1}\right)$. The seed quality was the lowest in the control treatment, without application of $\mathrm{Zn}$ and Mn. Amorim [16], Prete [35], and Lima et al. [59] observed inverse correlation between leached potassium, electrical conductivity, and cupping quality of coffee.

According to Amorim [65] and Chagas et al. [66], good coffees have high contents of sugars, around $8 \%$ according to Navellier [67] and around 5 to $10 \%$ according to Prete [35]. In general, the results of the first crop season were above the mean values reported by the literature.

It can also be noted that total acidity remained below $211.2 \mathrm{~g} \mathrm{NaOH} 100 \mathrm{~mL}^{-1}$ of the sample, considered by Carvalho et al. [2] as a parameter for good coffees. With repect to the $\mathrm{pH}$, it can also be observed that the mean of both years of assessment is quite close to that found by
Table 7: Caffeine (Caf, \%), trigonelline (Trig, \%), sucrose (Suc, \%), glucose (Glu, \%), galactose (Gal, \%), arabinose (Ara, \%), and mannose (Man, \%) of coffee beans harvested from plants submitted to the fertilization via solid salts injections in the trunk or foliar sprays with $\mathrm{B}, \mathrm{Cu}$, and $\mathrm{Zn}$, in the crop season 2011/2012.

\begin{tabular}{|c|c|c|c|c|c|c|c|}
\hline Treatm & Caf & Trig & Suc & Glu & Gal & Ara & Man \\
\hline \multicolumn{8}{|l|}{ Boron } \\
\hline WB & $1.01^{*}$ & $0.83^{*}$ & $5.14^{*}$ & $0.18^{*}$ & 0.10 & 0.03 & 0.14 \\
\hline FS & $1.51^{+}$ & $0.96^{+}$ & $6.45^{+}$ & $0.26^{+}$ & 0.14 & 0.03 & 0.15 \\
\hline B & $51^{+}$ & $0.98^{+}$ & $6.61^{+}$ & $0.28^{+}$ & 0.11 & 0.03 & 0.15 \\
\hline $\mathrm{B}+\mathrm{Cu}$ & $46^{+}$ & $0.96^{+}$ & $6.45^{+}$ & $0.28^{+}$ & $0.11^{*}$ & $0.05^{*}+$ & $0.17^{*,+}$ \\
\hline $\mathrm{B}+\mathrm{Zn}$ & $50^{+}$ & $0.99^{+}$ & $6.81^{+}$ & $0.35^{*}+$ & $0.16^{*}$ & $0.04^{*++}$ & 0.15 \\
\hline $\begin{array}{l}\mathrm{B}+\mathrm{Cu} \\
+\mathrm{Zn}\end{array}$ & $0.93^{*}$ & $0.85^{*}$ & $5.10^{*}$ & $0.24^{+}$ & 0 & 0.03 & 0.14 \\
\hline CV (\%) & 5.85 & 5.54 & 6.04 & 14.32 & 42.61 & 19.23 & 6.59 \\
\hline \multicolumn{8}{|l|}{ Copper } \\
\hline $\mathrm{WCu}$ & $01^{*}$ & $0.83^{*}$ & $5.14^{*}$ & $0.18^{*}$ & $0.10^{*}$ & 0.03 & $0.14^{*}$ \\
\hline FS & 1.5 & $0.96^{+}$ & $6.45^{+}$ & 0.2 & $4^{+}$ & 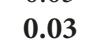 & $0.15^{+}$ \\
\hline $\mathrm{Cu}$ & + & $0.99^{+}$ & $6.01^{+}$ & $0.29^{+}$ & $0.10^{*}$ & 0.02 & $0.16^{*++}$ \\
\hline$B+C$ & $46^{+}$ & $0.96^{+}$ & $6.45^{+}$ & $0.28^{+}$ & $0.11^{*}$ & $0.05^{*}+$ & $0.17^{*,+}$ \\
\hline $\mathrm{Cu}+\mathrm{Zn}$ & $1.46^{+}$ & $0.97^{+}$ & $6.53^{+}$ & $0.30^{+}$ & 0.12 & 0.03 & $0.16^{+}$ \\
\hline $\begin{array}{l}\mathrm{B}+\mathrm{Cu} \\
+\mathrm{Zn}\end{array}$ & 09 & $0.85^{*}$ & $5.10^{*}$ & 028 & $011^{*}$ & 03 & 0.1 \\
\hline CV (\%) & 6.16 & 4.63 & 6.14 & 16.78 & 17.06 & 19.39 & 4.05 \\
\hline \multicolumn{8}{|l|}{ Zinc } \\
\hline WZn & 01 & $0.83^{*}$ & 5.1 & & & & $0.14^{*}$ \\
\hline FS & & $0.96^{+}$ & 6.4 & & & & $0.15^{+}$ \\
\hline $\mathrm{Zn}$ & $5^{+}$ & $0.99^{+}$ & $6.62^{+}$ & $0.31^{+}$ & 0.10 & $0.04^{*,+}$ & $0.16^{+}$ \\
\hline$B+2$ & $1.50^{+}$ & $0.99^{+}$ & $6.81^{+}$ & $0.35^{*,+}$ & 0.16 & $0.04^{*,+}$ & 0.15 \\
\hline $\mathrm{Cu}+$ & $1.46^{+}$ & $0.97^{+}$ & $6.53^{+}$ & $0.30^{+}$ & 0.12 & 0.03 & $0.16^{+}$ \\
\hline $\begin{array}{l}\mathrm{B}+\mathrm{Cu} \\
+\mathrm{Zn}\end{array}$ & $0.93^{*}$ & $0.85^{*}$ & $5.10^{*}$ & 0.24 & 0.11 & 0.03 & $0.14^{*}$ \\
\hline CV (\%) & 5.95 & 5.03 & 6.41 & 13.35 & 49.26 & 12.54 & 4.14 \\
\hline
\end{tabular}

$\mathrm{WB}, \mathrm{WCu}$, and $\mathrm{WZn}$ : control treatments, without application of $\mathrm{B}, \mathrm{Cu}$, and Zn, respectively; FS: foliar spray with boric acid, copper sulphate, and zinc sulphate (0.4\%); B: trunk injection of tablets containing B salts; $\mathrm{Cu}$ : trunk injection of tablets containing $\mathrm{Cu}$ salts; $\mathrm{Zn}$ : trunk injection of tablets containing $\mathrm{Zn}$ salts; $\mathrm{B}+\mathrm{Cu}$ : trunk injection of tablets containing $\mathrm{B}$ and $\mathrm{Cu}$ salts; $\mathrm{B}+\mathrm{Zn}$ : trunk injection of tablets containing $\mathrm{B}$ and $\mathrm{Zn}$ salts; $\mathrm{Cu}+\mathrm{Zn}$ : trunk injection of tablets containing $\mathrm{Cu}$ and $\mathrm{Zn}$ salts; $\mathrm{B}+\mathrm{Cu}+\mathrm{Zn}$ : trunk injection of tablets containing $\mathrm{B}, \mathrm{Cu}$, and $\mathrm{Zn}$ salts; ${ }^{*}$ mean values are statistically different from those of the control treatment (FS) at the $10 \%$ significance level, according to Dunnett's test; ${ }^{+}$mean values are statistically different from those of the control treatment (WB-WCu-WZn) at the $10 \%$ significance level, according to Dunnett's test.

Barrios [68] which was between 5.73 and 5.88. According to Sivetz and Desrosier [69], roasted beans of palatable coffees, without bitter or acidity, must have $\mathrm{pH}$ between 4.95 and 5.2. The results of the present work are slightly above the range established by this author.

Neves et al. [57] studying the effect of different doses of $\mathrm{Zn}$ supplied to coffee plants by trunk injections of tablets containing $\mathrm{Zn}$ salts observed that the electrical conductivities of the control treatment, without $\mathrm{Zn}$ application, were 22.61 and $88.42 \mu \mathrm{S} \cdot \mathrm{cm}^{-1} \cdot \mathrm{g}^{-1}$ in two consecutive crop seasons, respectively. For the treatments with $\mathrm{Zn}$ inserted into the trunk, the means of the electrical conductivities were 16.84 and $66.16 \mu \mathrm{S} \cdot \mathrm{cm}^{-1} \cdot \mathrm{g}^{-1}$. The average values of leached potassium were 1.13 and $0.95 \mathrm{~g} \cdot \mathrm{kg}^{-1}$, in two consecutive crop seasons, for the treatments without $\mathrm{Zn}$ application and 0.83 and $0.65 \mathrm{~g} \cdot \mathrm{kg}^{-1}$ for the treatments with $\mathrm{Zn}$ application. 
The difference among the treatments was attributed to the $\mathrm{Zn}$ functions on the cell membrane integrity of coffee beans.

Corrêa et al. [57] have also not observed variations in acidity of beans harvested from plants that received $\mathrm{Zn}$ by injection of tablets in the trunk, with the average values being $156.3 \mathrm{~mL}$ of $\mathrm{NaOH} 100 \mathrm{~g}^{-1}$, in coffees that were classified as "hard" in the cup test. In the same orchard, Martinez et al. [56] did not observe the effect of the nutrient on the total titratable acidity and $\mathrm{pH}$, with the average values being $14.7 \mathrm{~mL}$ of $\mathrm{NaOH} 100 \mathrm{~g}^{-1}$ and $5.4 \mathrm{~mL}$ of $\mathrm{NaOH}$ $100 \mathrm{~g}^{-1}$, respectively.

3.5. Caffeine, Trigonelline, Glucose, Galactose, Arabinose, and Mannose. In this study, the effect of $\mathrm{B}, \mathrm{Cu}$, and $\mathrm{Zn}$ on the caffeine, trigonelline, sucrose, and glucose productions was evident by the significant differences between the sprayed treatment and the treatments that received the nutrients via solid injections compared to the control treatments $\mathrm{WB}$, $\mathrm{WCu}$, and WZn (Table 7).

It is possible to observe the effect of the different ways of $\mathrm{B}, \mathrm{Cu}$, and $\mathrm{Zn}$ supply on the contents of caffeine, trigonelline, and sucrose by the difference between the treatments with $\mathrm{B}+\mathrm{Cu}+\mathrm{Zn}$ and the sprayed treatment (Table 7). The results suggest that the lack of $\mathrm{B}, \mathrm{Cu}$, and $\mathrm{Zn}$ influenced the route of caffeine and trigonelline synthesis, but probably the excessive concentrations of $\mathrm{B}$, like in the treatment containing $\mathrm{B}+\mathrm{Cu}+\mathrm{Zn}$, also did.

There was no effect of $\mathrm{B}$ on galactose production. The arabinose of the treatments containing $\mathrm{B}+\mathrm{Cu}$ and $\mathrm{B}+\mathrm{Zn}$ presented means statistically higher than those presented by the control treatment (WB). Regarding mannose, only the treatment containing $\mathrm{B}+\mathrm{Cu}$ was statistically different from the control treatment $\mathrm{WB}$, suggesting the effect of $\mathrm{B}$ on its production (Table 7).

The effect of $\mathrm{Cu}$ on mannose levels in the coffee beans was evidenced by the significant difference among the beans produced from the plants of the sprayed treatment and those receiving tablets of $\mathrm{Cu}, \mathrm{Cu}+\mathrm{B}$, and $\mathrm{Cu}+\mathrm{Zn}$ inserted in the trunk compared to the treatment $\mathrm{WCu}$. Regarding the levels of galactose, only the sprayed treatment differed from the treatment $\mathrm{WCu}$, and arabinose was significantly greater only in the treatment containing $\mathrm{Cu}+\mathrm{B}$ inserted in the trunk (Table 7).

With regard to the galactose, significant differences were not observed between the treatments with $\mathrm{Zn}$ applications. The arabinose content in beans of the treatments containing $\mathrm{Zn}$ and $\mathrm{Zn}+\mathrm{B}$ was statistically greater than that of the treatment WZn. Mannose of the sprayed treatment and of those receiving $\mathrm{Zn}$ and $\mathrm{Cu}+\mathrm{Zn}$ inserted in the trunk differed from that of the treatment WZn, showing the $\mathrm{Zn}$ effect on monosaccharides synthesis and the close relationship between its production and the content of $\mathrm{Zn}$ in index leaves (Table 7).

Mazzafera [70], working with nutritive solution and young coffee plants, did not found significant effects of $B$, $\mathrm{Cu}$, and $\mathrm{Zn}$ deprivation on the caffeine production by coffee leaves. The author states that the effect of mineral nutrients on the activity of methyltransferases involved in caffeine synthesis is still unclear.
The contents of trigonelline observed in this work, in general, are in agreement with those established by the literature that vary from 0.6 to $1.2 \%$ for Coffea arabica [71], and the caffeine contents are close to those determined by Screenath [72] of about $1.2 \%$ for Coffea arabica.

Within the monosaccharides and oligosaccharides, sucrose is a nonreducing sugar in greater quantity in coffee beans, varying from 1.9 to $10 \%$ of the dry matter $[73,74]$. According to Knopp et al. [75], sucrose represents more than $90 \%$ of the total low molecular weight carbohydrates and corresponds to $7.07 \%$ of the dry matter of coffee beans; this value is very close to that found in this experiment.

According to Camacho-Cristobal et al. [76], glucose 6phosphate, an enzyme involved in the glycolysis route, in conditions of B sufficiency appears complexed with borate anion and thus restricts the flow of the respiratory substrate to the pentose phosphate pathway; therefore, when B is adequate, the sucrose production is greater.

Brown and Clark [77] reported that $\mathrm{Cu}$-deficient wheat plants had significantly lower soluble carbohydrate contents than well-fertilized plants. The lower levels of plastocyanin, as a consequence of $\mathrm{Cu}$ deficiency, may decrease the efficiency of photosynthetic electron transport in photosystem I and thus impair the $\mathrm{CO}_{2}$ fixation rate, in such a way that starch and soluble sugars content (especially sucrose) are reduced.

Coffee bean contents of specific sugars such as mannose, gallactose, glucose, and arabinose were slightly lower than those previously reported by Fischer et al. [78] for Coffea arabica.

3.6. Caffeoylquinic Acids (3-CQA, 4-CQA, and 5-CQA), PPO Activity, and Phenolic Compounds. Among the phenolic compounds, caffeoylquinic acids, dicaffeoylquinic acids, and feruloylquinic acids are the main chlorogenic acid subgroups present in coffee. In general, these compounds react during the roasting process producing free phenolic acids and therefore volatile phenolic compounds that contribute to the aroma of coffee beans [37].

The effects of $\mathrm{B}, \mathrm{Cu}$, and $\mathrm{Zn}$ on 3-CQA and 5-CQA contents were evidenced by the significant difference between the treatments that received the nutrients via solid injections or foliar sprays and the treatments $\mathrm{WB}, \mathrm{WCu}$, and WZn. Compared to the sprayed treatment, only the treatment with $\mathrm{B}+\mathrm{Cu}+\mathrm{Zn}$ differed significantly, for 5-CQA content, responding to the different ways of $\mathrm{B}, \mathrm{Cu}$, and $\mathrm{Zn}$ supply (Table 8).

The 4-CQA, proanthocyanidin, and total phenolic compounds were not affected by B treatments. The effect of $\mathrm{Cu}$, also, was not significant for the contents of 4-CQA and proanthocyanidin. For Zn, 4-CQA and proanthocyanidin were not significant (Table 8).

The effect of B on PPO activity was evidenced by the significant difference of the treatments with $\mathrm{B}+\mathrm{Cu}$ and the sprayed treatment compared to the treatment $\mathrm{WB}$, even when $\mathrm{B}$ concentration in the index leaves of the treatment that received $\mathrm{B}$ by trunk injections was above the adequate range established by Martinez et al. [43]. 
TABLE 8: 3-Caffeoylquinic acid (3-CQA, \%), 4-caffeoylquinic acid (4-CQA, \%), 5-caffeoylquinic acid (5-CQA, \%), proanthocyanidin (Pro, \%), polyphenol oxidase activity (PPO, U. $\left.\mathrm{min}^{-1} \cdot \mathrm{g}^{-1}\right)$, and phenolic compounds (TP, \%) of coffee beans harvested from plants submitted to the fertilization via solid salts injections in the trunk or foliar sprays with B, Cu, and $\mathrm{Zn}$, in the crop season 2011/2012.

\begin{tabular}{|c|c|c|c|c|c|c|}
\hline Treatments & 3-CQA & 4-CQA & 5-CQA & Pro & $\mathrm{PPO}$ & $\mathrm{TP}$ \\
\hline \multicolumn{7}{|l|}{ Boron } \\
\hline WB & $0.65^{*}$ & 0.73 & $1.69^{*}$ & 6.36 & $74.52^{*}$ & 6.37 \\
\hline FS & $0.44^{+}$ & 0.72 & $1.41^{+}$ & 5.70 & $85.93^{+}$ & 5.15 \\
\hline B & $0.44^{+}$ & 0.58 & $1.35^{+}$ & 5.53 & 82.07 & 4.21 \\
\hline $\mathrm{B}+\mathrm{Cu}$ & $0.47^{+}$ & 0.66 & $1.40^{+}$ & 6.78 & $85.50^{+}$ & 4.61 \\
\hline $\mathrm{B}+\mathrm{Zn}$ & $0.45^{+}$ & 0.64 & $1.38^{+}$ & 7.14 & 78.38 & 5.50 \\
\hline $\mathrm{B}+\mathrm{Cu}+\mathrm{Zn}$ & 0.52 & 0.61 & $1.58^{*}$ & 6.41 & $74.68^{*}$ & 6.13 \\
\hline CV (\%) & 19.89 & 22.27 & 6.36 & 38.15 & 9.01 & 24.59 \\
\hline \multicolumn{7}{|l|}{ Copper } \\
\hline $\mathrm{WCu}$ & $0.65^{*}$ & 0.73 & $1.69^{*}$ & 6.36 & $74.53^{*}$ & 6.38 \\
\hline FS & $0.44^{+}$ & 0.72 & 1.4 & 5.70 & $85.93^{+}$ & 5.15 \\
\hline $\mathrm{Cu}$ & $0.4 / 7$ & 0.75 & $1.40^{+}$ & 6.23 & $85.15^{+}$ & $4.06^{+}$ \\
\hline $\mathrm{B}+\mathrm{Cu}$ & $0.47^{+}$ & 0.66 & $1.39^{+}$ & 6.78 & $85.51^{+}$ & 4.61 \\
\hline $\mathrm{Cu}+\mathrm{Zn}$ & $0.44^{+}$ & 0.62 & $1.30^{+}$ & 7.59 & $85.19^{+}$ & 4.87 \\
\hline $\mathrm{B}+\mathrm{Cu}+$ & $0.52^{+}$ & 0.61 & $1.58^{*}$ & 6.41 & $74.68^{*}$ & 6.14 \\
\hline $\mathrm{CV}(9$ & 16.10 & 14.37 & 5.45 & 37.40 & 6.25 & 22.57 \\
\hline \multicolumn{7}{|l|}{ Zinc } \\
\hline \multicolumn{7}{|l|}{ WZn } \\
\hline $\mathrm{T}$ & $65 *$ & 0.7 & $1.69^{*}$ & 6.36 & $74.52^{*}$ & $6.37^{*}$ \\
\hline FS & $0.44^{+}$ & 0.72 & $1.41^{++}$ & 5.70 & $85.93^{+}$ & $5.15^{+}$ \\
\hline $\mathrm{Zn}$ & $0.48^{+}$ & 0.74 & $1.41^{+}$ & 7.21 & 79.08 & 5.70 \\
\hline $\mathrm{B}+\mathrm{Zn}$ & $0.45^{+}$ & 0.64 & $1.38^{+}$ & 7.14 & 78.38 & 5.50 \\
\hline $\mathrm{Cu}+\mathrm{Zn}$ & $0.44^{+}$ & 0.61 & $1.30^{+}$ & 7.59 & $85.19^{+}$ & $4.87^{+}$ \\
\hline $\mathrm{B}+\mathrm{Cu}+\mathrm{Zr}$ & $0.52^{+}$ & 0.60 & $1.58^{*}$ & 6.41 & $74.68^{*}$ & 6.13 \\
\hline CV (\%) & 16.25 & 18.28 & 6.08 & 31.93 & 7.11 & 14.01 \\
\hline
\end{tabular}

$\mathrm{WB}, \mathrm{WCu}$, and $\mathrm{WZn}$ : control treatments, without application of $\mathrm{B}, \mathrm{Cu}$, and $\mathrm{Zn}$, respectively; FS: foliar spray with boric acid, copper sulphate, and zinc sulphate $(0.4 \%)$, B: trunk injection of tablets containing B salts, Cu: trunk injection of tablets containing $\mathrm{Cu}$ salts, $\mathrm{Zn}$ : trunk injection of tablets containing $\mathrm{Zn}$ salts, $\mathrm{B}+\mathrm{Cu}$ : trunk injection of tablets containing $\mathrm{B}$ and $\mathrm{Cu}$ salts, $\mathrm{B}+\mathrm{Zn}$ : trunk injection of tablets containing $\mathrm{B}$ and $\mathrm{Zn}$ salts, $\mathrm{Cu}+\mathrm{Zn}$ : trunk injection of tablets containing $\mathrm{Cu}$ and $\mathrm{Zn}$ salts, $\mathrm{B}+\mathrm{Cu}+\mathrm{Zn}$ : trunk injection of tablets containing $\mathrm{B}, \mathrm{Cu}$, and $\mathrm{Zn}$ salts; ${ }^{*}$ mean values are statistically different from those of the control treatment (FS) at the $10 \%$ significance level, according to Dunnett's test; ${ }^{+}$mean values are statistically different from those of the control treatment (WB-WCu-WZn) at the $10 \%$ significance level, according to Dunnett's test.

It is suggested that the content of B that is good for great growth and production is below the content that maximizes the PPO activity, a feature that has been directly related to cupping quality (Tables 2 and 8 ).

A significant difference was observed between the sprayed treatment and the treatments with $\mathrm{Cu}, \mathrm{Cu}+\mathrm{B}$, and $\mathrm{Cu}+\mathrm{Zn}$ compared to the treatment $\mathrm{WCu}$ for the PPO activity, with a particular focus on the clear inverse relationship between the PPO activity and the concentration of 5-CQA in the beans (Table 8).

Even though average leaf $\mathrm{Cu}$ concentrations of sprayed treatments were somewhat lower than those of trunk injection treatments, they were still within the sufficiency range reported in the literature of Martinez et al. [43]. It suggests that the composition of caffeoylquinic acids and PPO activity remained constant within the range of $\mathrm{Cu}$ concentration in the index leaves, which indicates adequate nutrition (Tables 2 and 8).

Regarding the $\mathrm{Zn}$ nutrition, the PPO activity, and contents of total phenolic compounds, only the treatment with $\mathrm{Zn}+\mathrm{Cu}$ and the sprayed treatment differed from the treatment WZn, with the highest activity being observed when phenolic compounds concentrations were low (Table 8).

For the PPO activity, compared with the sprayed treatment, all treatments that received $\mathrm{B}, \mathrm{Cu}$, and $\mathrm{Zn}$ via solid injections, except $\mathrm{B}+\mathrm{Cu}+\mathrm{Zn}$, are statistically similar, confirming the equal effect of different ways of supply of the studied micronutrients (Table 8).

Several works, in the literature, relate the accumulation of caffeoylquinic acids to B deficiency. Camacho-Cristobal et al. [76] reported that the main effect of B deficiency is the accumulation of glucose, fructose, and starch, followed by an increase in the 3-CQA, 4-CQA, and 5-CQA contents in tobacco leaves. Therefore, the high concentration of phenolic compounds, in B-deficient plants, could be a result of the soluble sugars accumulation [5].

Camacho-Cristobal et al. [79] attributed this effect to the enhancement of the phenylalanine ammonia lyase activity and consequent increase in the phenolic compounds synthesis. Additionally, according to this author, when in high concentration, B and glucose 6-phosphate form complexes and therefore restrict the flow of the respiratory substrate for the pentose phosphate pathway. Such a behavior may explain the enhanced concentrations of the 3-CQA and 5-CQA in the control treatment $\mathrm{WB}, \mathrm{WCu}$, and $\mathrm{WZn}$.

In addition, phenolic compounds accumulation is a feature of B-deficient plants because of the formation of borate complexes with some phenols that can be involved in the regulation of free phenol concentration and in the alcohol phenol synthesis, which are direct precursors of the lignin [80].

A strong relationship between caffeoylquinic acid contents and cupping quality was not observed in the present study. Coffee beans from the control treatment (WB-WCuWZn) had an average score of 82.7 and were hence classified as "soft."

3.7. PPO. Hajiboland and Farhanghi [81] studying the effect of adequate and low doses of $B$ in turnip plants observed that PPO activity and phenolic compounds increased in roots and shoot when the B supply was low. The PPO activity in leaves and roots of deficient plants was 6.3 and 4.6 folds higher, respectively, than that of the control plants receiving sufficient B.

According to Karabal et al. [82], excess of B alters the cell membrane integrity; thus, a progressive increase in PPO activity is observed initially followed by falling, because of quinones production that inhibits the enzyme, which may explain the low PPO activity of the treatment containing $\mathrm{B}+\mathrm{Cu}+\mathrm{Zn}$ inserted into the trunk.

Carvalho et al. [2] proposed a way to assess the coffee quality using PPO activity levels. According to them, "rio" and "rioysh" types are well correlated to PPO activities below $55.99 \mathrm{U} \cdot \mathrm{min}^{-1} \cdot \mathrm{g}^{-1}$ of the sample; hard type is correlated to 
activities between 55.99 and $62.99 \mathrm{U} \cdot \mathrm{min}^{-1} \cdot \mathrm{g}^{-1}$ of the sample; soft type is correlated to activities between 62.99 and $67.66 \mathrm{U} \cdot \mathrm{min}^{-1} \cdot \mathrm{g}^{-1}$ of the sample, and strictly soft type is correlated to activities above $67.99 \mathrm{U} \cdot \mathrm{min}^{-1} \cdot \mathrm{g}^{-1}$ of the sample.

In the present work, it is not possible to establish a good relationship between cupping quality and $\mathrm{PPO}$ activity, since the treatments $\mathrm{WB}, \mathrm{WCu}, \mathrm{WZn}$, and with $\mathrm{B}+\mathrm{Cu}+\mathrm{Zn}$ had high cupping test scores (82.7 to controls and 80.4 to combination: "soft" type) followed by low PPO activity. It can be highlighted, however, that low PPO activity in these treatments was accompanied by high concentrations of 3 CQA and 5-CQA.

According to Mazzafera and Robinson [83], the 5-CQA is likely the main substrate of the PPO. Farah et al. [23] stated that there is an increase in the coloration intensity of coffee beans in response to the PPO action on 5-CQA; thus, the authors associated the oxidation products with the low quality of coffee beans rich in caffeoylquinic acid. Amorim et al. [84] reported that PPO action, along the structural changes of the membrane, is a possible cause for the formation of beans classified as "rioysh" type.

It is often mentioned by the literature that $\mathrm{Cu}$ is the PPO catalyst [85]; thus, the evaluation of PPO activity can be a good indicator of the nutritional status in $\mathrm{Cu}$. Taking into account the importance of $\mathrm{Cu}$ on the PPO structure and because of the enzyme involved in the control of the concentration of free phenolic compounds, the efficiency in $\mathrm{Cu}$ supplementation to the plants is, therefore, a requirement of great importance in order to obtain coffees with higher quality.

In a nutritive solution experiment [86], it was observed that $\mathrm{Zn}$ doses affected the contents of chlorogenic acids of Coffea arabica beans. Total phenolic compounds, 5-CQA, and 4-CQA reached minimum points when the index leaves presented $10 \mathrm{mg} \cdot \mathrm{kg}^{-1}$ of $\mathrm{Zn}$, that is about in the center of the sufficiency range established by Martinez et al. [43]. The grains produced in conditions of deficiency or excess of $\mathrm{Zn}$ presented higher values of these compounds. The curves for PPO and 3-CQA presented exactly an inverse shape, reaching the maximum points in grains of plants with $10 \mathrm{mg} \cdot \mathrm{kg}^{-1}$ of $\mathrm{Zn}$ in index leaves. Due to the direct relationship between 3-CQA and PPO, the author questioned if the content of 3-CQA, in a different way from that of 5CQA, could be related to good quality of coffee beans.

Although, in this work, there was no good agreement between the cupping test and chemical attributes of coffee quality, it should be emphasized that the cupping test is subjective and new methods must be studied in order to evaluate properly the coffee bean quality.

\section{Conclusions}

Boron, copper, and zinc supplied by foliar sprays or solid trunk injections influence the chemical composition and quality of the coffee beans, characterized by the contents of caffeine, trigonelline, sucrose, glucose, arabinose, mannose, 3-caffeoylquinic acid, 5-caffeoylquinic acid, polyphenol oxidase activity, and total phenolic compounds.
Copper and $\mathrm{Zn}$ supplied by solid trunk injections give equivalent results to foliar sprays, both in production and quality.

Trunk injections of tablets containing B salts resulted in toxicity and affected negatively the production, while some attributes related to the quality of the grains were higher with high B supply, capable of limiting the growth and yield of coffee plants.

\section{Disclosure}

This paper is part of the Ph.D. thesis presented to the Universidade Federal de Viçosa, Viçosa, Brazil, by the first author.

\section{Conflicts of Interest}

The authors declare that they have no conflicts of interest.

\section{Acknowledgments}

The authors would like to thank the financial support of the Brazilian government agencies Conselho Nacional de Desenvolvimento Científico e Tecnológico (CNPq) and Coordenação de Aperfeiçoamento de Pessoal de Nível Superior (CAPES).

\section{References}

[1] E. Cantergiani, H. Brevard, Y. Krebs, A. Feria-Morales, R. Amadò, and C. Yeretzian, "Characterization of mouldy/ earthy defect in green Mexican coffee," in Colloquium of International Coffee Science Association, Vol. 18, ASIC, Helsinki, Finland, 1999.

[2] V. D. Carvalho, S. M. Calfoun, S. J. R. Chagas, N. Botrel, and E. S. G. Juste Júnior, "Relações entre a composição físicoquímica e química do grão beneficiado e da qualidade de bebida do café. Pesquisa Agropecuária Brasileira," Brasília, vol. 29, no. 3, pp. 449-454, 1994.

[3] E. Malavolta, "Nutrição, adubação e calagem para o cafeeiro," in Cultura do Cafeeiro: Fatores que Afetam a Produtividade, A. B. Rena, E. Malavolta, M. Rocha, and T. Yamada, Eds., pp. 136-274, Potafos, Piracicaba, Brazil, 1986.

[4] R. M. Prado, Nutrição de Plantas, UNESP, Jaboticabal, Brazil, 2008.

[5] H. Marschner, Mineral Nutrition of Higher Plants, Academic Press, New York, NY, USA, 2011.

[6] J. R. Sanders, T. M. Adams, and B. T. Christensen, "Extractability and bioavailability of zinc, nickel, cadmium and copper in three Danish soils sampled 5 years after application of sewage sludge," Journal of Science Food and Agriculture, vol. 37, pp. 1155-1164, 1986.

[7] N. K. Fageria, V. C. Baligar, and R. B. Clark, Micronutrients in Crop Production, Vol. 77, Advances in Agronomy, New York, NY, USA, 2002.

[8] E. Epstein and A. J. Bloom, Nutrição Mineral de Plantas: Princípios e Perspectivas, Planta, Londrina, Brazil, 2nd edition, 2006.

[9] K. Mengel and E. A. Kirkby, Principles of Plant Nutrition, Internacional Potash Institute, Horgen, Switzerland, 4th edition, 1987.

[10] R. Hansch and R. R. Mendel, "Physiological functions of mineral micronutrients $(\mathrm{Cu}, \mathrm{Zn}, \mathrm{Mn}, \mathrm{Fe}, \mathrm{Ni}, \mathrm{Mo}, \mathrm{B}, \mathrm{Cl})$," 
Current Opinion in Plant Biology, vol. 12, no. 3, pp. 259-266, 2009.

[11] I. Cakmak, H. Marschner, and F. Bangerth, "Effect of zinc nutritional status on growth, protein metabolism and levels of indole- 3 acetic acid and other phytohormones in bean (Phaseolus vulgaris L.)," Journal Experimental Botany, vol. 40, pp. 405-412, 1989.

[12] G. S. Valladares, G. C. G. Santos, C. A. Abreu, O. A. Camargo, and J. P. Ferrero, Zinco Total e Disponível em Amostras de Perfis de Solos do Estado de São Paulo, Bragantia, vol. 68, no. 4, pp. 1105-1114, Bragantia, Campinas, Brazil, 2009.

[13] R. H. Santori, A. E. Boaretto, F. C. A. Villanueva, and H. M. G. Fernandes, "Absorção radicular e foliar de ${ }^{65} \mathrm{Zn}$ e sua redistribuição em laranjeiras," Revista Brasileira de Fruticultura, vol. 30, no. 2, pp. 523-527, 2008.

[14] N. A. V. D. Pinto, S. M. R. Fernandes, R. G. F. A. Giranda, and V. D. Carvalho, "Avaliação de componentes químicos de padrões de bebida para preparo do café expresso. Ciência e Agrotecnologia," Lavras, vol. 26, no. 4, pp. 826-829, 2002.

[15] P. F. P. Goulart, J. D. Alves, E. M. Castro, D. D. Fries, M. M. Magalhães, and H. C. Melo, "Histological and morphological aspects of different grain coffee qualities," Ciência Rural, vol. 37, pp. 662-666, 2007.

[16] V. H. Amorim, Aspectos Bioquímicos do Grão de Café Verde Relacionados Com a Deterioração da Qualidade, Tese de Livre Docência, p. 85, ESALQ-USP, Piracicaba, Brazil, 1978.

[17] S. J. Chagas, V. D. Carvalho, and L. Costa, "Caracterização química e qualitativa de cafés de alguns municípios de três regiões produtoras de Minas Gerais," Pesquisa Agropecuária Brasileira, vol. 31, pp. 555-561, 1996.

[18] L. C. Trugo and R. A. Macrae, "Chlorogenic acid composition of instant coffee," Analyst, vol. 109, pp. 263-266, 1984.

[19] M. N. Clifford and K. C. Wilson, Coffee: Botany, Biochemistry and Production of Beans Beverage, Croom Helm, New York, NY, USA, 1985.

[20] C. P. Bicchi, O. M. Panero, G. M. Pellegrino, and A. C. Vanni, "Characterization of green and roasted coffees through the chlorogenic acid fraction by HPLC-UV and principal component analysis," Journal of Agricultural and Food Chemistry, vol. 43, no. 6, pp. 1549-1555, 1995.

[21] M. Nogueira and L. C. Trugo, "Distribuição de isômeros de ácido clorogênico e teores de cafeína e trigonelina em cafés solúveis brasileiros," Ciência e Tecnologia de Alimentos, vol. 23, no. 2, pp. 296-299, 2003.

[22] H. Morais, P. H. Caramori, M. S. Koguishi, J. C. Gomes, and A. M. Ribeiro, "Sombreamento de cafeeiros durante o desenvolvimento das gemas florais e seus efeitos sobre a frutificação e produção," Ciência Rural, vol. 39, pp. 400-406, 2009.

[23] A. Farah, M. C. Monteiro, V. Calado, A. S. Franca, and E. L. C. Trugo, "Correlation between cup quality and chemical attributes of Brazilian coffee," Food Chemistry, vol. 98, no. 2, pp. 373-380, 2006.

[24] M. C. Monteiro and L. C. Trugo, "Determinação de compostos bioativos em amostras comerciais de café torrado," Química Nova, vol. 28, pp. 637-641, 2005.

[25] E. B. Fagan, C. H. E. Souza, N. M. B. Pereira, and V. J. Machado, "Efeito do tempo de formação do grão de café (Coffea sp.) na qualidade da bebida," Bioscience Journal, vol. 27, pp. 729-738, 2011.

[26] P. T. G. Guimarães, A. W. R. Garcia, V. H. Alvarez et al., "Cafeeiro," in Recomendações Para o Uso de Corretivos e Fertilizantes em Minas Gerais- $5^{a}$ Aproximação, A. C. Ribeiro, P. T. G. Guimarães, and V. H. Alvarez, Eds., pp. 289-302, Viçosa, MG, Brazil, 1999.
[27] E. Malavolta, G. C. Vitti, and S. A. Oliveira, Avaliação do Estado Nutricional das Plantas: Princípios e Aplicações, Potafos, Piracicaba, Brazil, 2nd edition, 1997.

[28] Association of Official Analytical Chemists, Official Methods of Analysis, AOAC, Washington, DC, USA, 12th edition, 1975.

[29] C. M. Johnson and A. Ulrich, Analytical Methods for Use in Plants Analyses, University of California, Los Angeles, CA, USA, 1959.

[30] N. S. Sakyiama, H. E. P. Martinez, M. A. Tomaz, and A. Borém, Café Arábica: do Plantio à Colheita, UFV, Viçosa, MG, Brazil, 2015.

[31] Association of Official Analytical Chemists, Official Methods of Analyses of the Association of Official Analytical Chemists, AOAC, Washington, DC, USA, 15th edition, 1975.

[32] N. Nelson, "A photometric adaptation of Somogy method for the determination of glucose," Journal of Biological Chemists, vol. 153, no. 1, pp. 370-380, 1944.

[33] V. L. Singleton, "The total phenolic content of grape berries during the maturation of several varieties," American Journal of Enology and Viticulture, vol. 17, no. 2, pp. 126-134, 1966.

[34] T. M. Loeffler, D. M. Tekrony, and D. B. Egli, "The bulk conductivity test as an indicator of soybean seed quality," Journal of Seed Technology, vol. 12, no. 1, pp. 37-53, 1988.

[35] C. E. C. Prete, "Condutividade elétrica do exsudado de grãos de café (Coffea arabica L.). Desenvolvimento da metodologia," Ciências Agrárias, vol. 21, no. 1, pp. 67-70, 1995.

[36] J. D. Ponting and M. A. Joslyn, "Ascorbic acid oxidation and browning in apple tissue extracts," Archives of Biochemistry, vol. 19, pp. 47-63, 1948.

[37] A. Farah, T. De Paulis, L. C. Trugo, and P. R. Martin, "Effect of roasting on the formation of chlorogenic acid lactones in coffee," Journal of Agricultural and Food Chemistry, vol. 53, no. 5, pp. 1505-1513, 2005.

[38] P. Mazzafera, A. Crozier, and G. Sandberg, "Studies on the metabolic control of caffeine turnover in developing endosperms and leaves of Coffea arabica and Coffea dewevrei," Journal of Agricultural and Food Chemistry, vol. 42, no. 7, pp. 1423-1428, 1994.

[39] M. D. Vitorino, A. S. França, L. S. Oliveira, and M. L. A. Borges, "Metodologias de obtenção de extrato de café visando a dosagem de compostos não voláteis," Revista Brasileira de Armazenamento, vol. 26, no. 3, pp. 17-24, 2001.

[40] A. E. Hagerman, Y. Zhao, S. E. Johnson, and F. Shahadi, "Methods for determination of condensed and hydrolyzable tannins," ACS Symposium Series, vol. 662, pp. 209-222, 1997.

[41] A. Sluiter, B. Hames, R. Ruiz et al., Determination of Structural Carbohydrates and Lignin in Biomass. Laboratory Analytical Procedure, General Books LLC, Memphis, Tennessee, 2008.

[42] SAEG-System of Statistical Analysis and Genetics, Versão 9.1: Fundação Arthur Bernardes, Viçosa, Brazil, 2007.

[43] H. E. P. Martinez, J. F. S. Menezes, R. B. Souza, V. H. Alvarez-Venegas, and P. T. G. Guimarães, "Faixas críticas de concentração de nutrientes e avaliação do estado nutricional de cafeeiros em quatro regiões de Minas Gerais," Pesquisa Agropecuária Brasileira, vol. 38, no. 6, pp. 703-713, 2003.

[44] P. H. Brown and B. J. Shelp, "Boron mobility in plants," Plant soil, vol. 193, pp. 85-101, 1997.

[45] P. H. Brown and H. Hu, "Phloem boron mobility in diverse plant species," Botany Acta, vol. 111, pp. 331-335, 1998.

[46] F. Santinato, F. L. Castanehira, R. M. Prado, and R. Santinato, "Efeito da aplicação de doses elevadas de ácido bórico em cafeeiro jovem, Catuaí Vermelho IAC 144," in Congresso Brasileiro de Pesquisas Cafeeiras, vol. 38, pp. 243-244, Procafé, Caxambu, RJ, Brazil, 2012. 
[47] O. F. Lima Filho and E. Malavolta, "Calibração de boro e zinco para o cafeeiro (Coffea arabica L. cv. Catuaí Amarelo)," in Reunião Brasileira de Fertilidade do Solo e Nutrição de Plantas, vol. 20, pp. 54-55, Potafos, Piracicaba, Brazil, 1992.

[48] A. B. Rena and M. Maestri, "Fisiologia do cafeeiro," Informe Agropecuário, vol. 11, pp. 26-40, 1985.

[49] R. Santinato, R. P. Camargo, R. B. Batista, and E. M. Pereira, "Quantificação de boro orgânico (ager boro) via foliar para o cafeeiro, seu efeito sobre aplicação na florada e seu comportamento no solo," in Congresso Brasileiro De Pesquisas Cafeeiras, vol. 20, Águas de Lindóia, Brazil, 1994.

[50] U. V. Barros, R. Santinato, and J. B. Matiello, "Fontes, doses e método de aplicação de B no plantio de café na região da Zona da Mata em Minas Gerais," in Congresso Brasileiro De Pesquisas Cafeeiras, vol. 22, pp. 117-118, Instituto Brasileiro do Café, Águas de Lindóia, Brazil, 1996.

[51] V. M. M. Andrade, Influência do Cobre no Crescimento, Morfologia e Anatomia da Folha e na Composição Mineral do Cafeeiro, Tese (Doutorado), Universidade Estadual de São Paulo, Jaboticabal, Brazil, 1973.

[52] J. R. Loneragan, "The availability and absorption of trace elements in soil-plants systems and their relation to movement and concentrations of trace elements in plant," in Trace Elements in Soil-Plant-Animal Systems, D. J. D. Nicholas and A. R. Egan, Eds., pp. 109-134, Academic Press, Cambridge, London, 1975.

[53] W. Reuther and C. K. Labanauskas, "Copper," in Diagnosis criteria for plants and soils, H. C. Chapman, Ed., pp. 157-179, University of California, CA, USA, 1966.

[54] P. T. G. Guimarães, J. C. Carvalho, C. C. A. Melles, and E. Malavolta, "Efeitos da aplicação foliar de sulfato de Zn na produção e na composição mineral das folhas de cafeeiro (Coffea arabica L.)," Anais da ESALQ, vol. 40, pp. 497-507, 1983.

[55] O. F. Lima Filho and E. Malavolta, "Evaluation of extraction procedures on determination of critical soil and foliar levels of boron and zinc in coffee plants," Commununications in Soil Science and Plant Analysis, vol. 29, pp. 825-833, 1998.

[56] H. E. P. Martinez, Y. Poltronieri, A. Farah, and D. Perrone, "Zinc supplementation, production and quality of coffee beans," Revista Ceres, vol. 60, no. 2, pp. 293-299, 2013.

[57] Y. P. Neves, H. E. P. Martinez, and P. R. Cecon, "Effect of zinc and its form of supply on production and quality of coffee beans," Journal of Science Food and Agricultural, vol. 91, pp. 2431-2436, 2011.

[58] P. C. Corrêa, P. C. Afonso Junior, F. A. C. Pinto, and T. T. Oliveira, "Efeito da temperatura de secagem na cor dos grãos de café pré-processados por via seca e via úmida," Revista Brasileira de Armazenamento, vol. 5, pp. 22-27, 2002.

[59] M. V. Lima, H. D. Vieira, M. L. L. Martins, and S. M. F. Pereira, "Preparo do café despolpado, cereja descascado e natural na região sudoeste da Bahia," Revista Ceres, vol. 55, pp. 124-130, 2008.

[60] W. Heydecker Vigour, in Viability on Seeds, E. D. Roberts, Ed., pp. 209-252, University Press, Syracuse, NY, USA, 1972.

[61] J. F. Harrington, "Problems of seed storage," in Seed Ecology, W. Heydecker, Ed., pp. 251-263, The Pennsylvania State University Press, University Park, PA, USA, 1973.

[62] M. R. Malta, M. L. Santos, and F. A. M. Silva, "Qualidade de grãos de diferentes cultivares de cafeeiro (Coffea arabica L.)," Acta Scientiarum, vol. 24, no. 5, pp. 1385-1390, 2002.

[63] A. D. Lima, T. V. A. Viana, B. M. Azevedo, A. B. Marinho, and J. M. L. Duarte, "Adubação borácica na cultura do girassol," RevistaAgro@mbiente, vol. 7, no. 3, pp. 269-276, 2013.
[64] I. R. Teixeira, A. Borém, G. A. A. Araújo, and M. J. B. Andrade, Teores de Nutrientes e Qualidade Fisiológica de Sementes de Feijão em Resposta à Adubação Foliar com Manganês e Zinco, vol. 64, no. 1, pp. 83-88, Bragantia, Campinas, Brazil, 2005.

[65] H. V. Amorim, M. G. Legendre, V. L. Amorim, A. J. S. Angelo, and R. L. Ory, "Chemistry of Brazilian green coffee and the quality of the beverage. VII. Total carbanyls, activity of polyphenol oxidase, and hydroperoxides," Turrialba, vol. 26, no. 2, pp. 193-195, 1976.

[66] S. J. R. Chagas, V. D. Carvalho, L. Costa, and M. M. Romaniello, "Caracterização química e qualitativa de cafés de alguns municípios de três regiões produtoras de Minas Gerais. II-valores de acidez titulável total e teores de açúcares (redutores, não redutores e totais)," Ciência $e$ Agrotecnologia, vol. 20, no. 2, pp. 224-231, 1996.

[67] P. Navellier, "Coffee," in Encyclopedia of Industrial Chemical Analysis, vol. 19, pp. 73-447, John Wiley \& Sons, New York, NY, USA, 1970.

[68] B. B. E. Barrios, Caracterização Física, Química, Microbiológica e Sensorial de Cafés (Coffea arábica L.) da Região Alto Rio Grande-Sul de Minas Gerais, Dissertações (Mestrado em Ciência dos Alimentos), p. 72, Universidade Federal de Lavras, Lavras, 2001.

[69] M. Sivetz and N. W. Desrosier, Coffee Technology, Avi, Westport, CT, USA, 1979.

[70] P. Mazzafera, "Mineral nutrition and caffeine content in coffee leaves," Bragantia, vol. 58, no. 2, pp. 387-391, 1999.

[71] A. Illy and R. Viani, Espresso Coffee: The Chemistry of Quality, Academic Press, San Diego, CA, USA, 1995.

[72] H. L. Screenath, Development of Caffeine in Free Coffee Varieties, vol. 61, no. 10, Indian Coffee, Bangalore, India, 1997.

[73] M. L. Wolfrom, R. A. Plunkert, and M. L. Laver, "Carbohydrates of the coffee bean," Journal of Agricultural and Food Chemistry, vol. 8, no. 1, pp. 58-65, 1960.

[74] J. R. Feldman, W. S. Ryder, and J. T. Kung, "Importance of non-volatile compounds to the flavor of coffee," Journal of Agriculture and Food Chemistry, vol. 17, no. 4, pp. 733-739, 1969.

[75] S. Knopp, G. Bytof, and D. Selmar, "Influence of processing on the content of sugars in green Arabica coffee beans," European Food Research and Technology, vol. 223, no. 2, pp. 195-201, 2006.

[76] J. J. Camacho-Cristobal, L. Lunar, F. Lafont, A. Baumert, and A. Gonzales-Fontes, "Boron deficiency causes accumulation of chlorogenic acid and caffeoyl polyamine conjugates in tobacco leaves," Journal of Plant Physiology, vol. 161, no. 7, pp. 879-881, 2004.

[77] J. C. Brown and R. B. Clark, "Copper as essential to wheat reproduction," Plant Soil, vol. 48, no. 2, pp. 509-523, 1977.

[78] M. Fischer, S. Reimann, V. Trovato, and R. J. Redgwell, "Polysaccharides of green Arabica and Robusta coffee beans," Carbohydrate Research, vol. 330, no. 1, pp. 93-101, 2001.

[79] J. J. Camacho-Cristobal, D. Anzellotti, and A. GonzalezFontes, "Changes in phenolic metabolism of tobacco plants during short-term boron deficiency," Plant Physiology Biochemistry, vol. 40, no. 12, pp. 997-1002, 2002.

[80] D. J. Pilbeam and E. A. Kirkby, "The physiological role of boron in plants," Journal of Plant Nutrition, vol. 6, no. 7, pp. 363-382, 1983.

[81] R. Hajiboland and F. Farhanghi, "Remobilization of boron, photosynthesis, phenolic metabolism and anti-oxidant defense capacity in boron-deficient turnip (Brassica rapa L.) plants," Soil Science Plant Nutrition, vol. 56, no. 3, pp. 427437, 2010. 
[82] E. Karabal, M. Yücel, and H. A. Öktem, "Antioxidant responses of tolerant and sensitive barley cultivars to boron toxicity," Plant Science, vol. 164, no. 6, pp. 925-933, 2003.

[83] P. Mazzafera and S. P. Robinson, "Characterization of polyphenol oxidase in coffee," Phytochemistry, vol. 55, pp. 285-296, 2000.

[84] H. V. Amorim, A. R. Cruz, S. T. Angelo, A. J. Dias, R. M. Mello, and A. A. Teixeira, "Biochemical, physical and organoleptical changes during raw coffee quality deterioration," in Proceedings of 8th International Colloq Coffee, Abidjan, Côte d'Ivoire, December 1977.

[85] E. Malavolta, Elementos de Nutrição Mineral de Plantas, Agronômica Ceres, São Paulo, Brazil, 1980.

[86] J. S. Lacerda, Produção, Composição Química e Qualidade da Bebida de Café Arábica em Razão da Dose de Cobre e Zinco, Tese de Doutorado, Universidade Federal de Viçosa, Viçosa, Brazil, 2014.

[87] J. M. Clemente, Boron, Copper and Zinc Effects on Photosynthesis, Enzymatic Activity, Nutritional Status, Production, Chemical Composition and Cup Quality of Coffee, Tese (Doutorado em Fitotecnia), p. 115, Universidade Federal de Viçosa, Viçosa, MG, Brazil, 2014. 


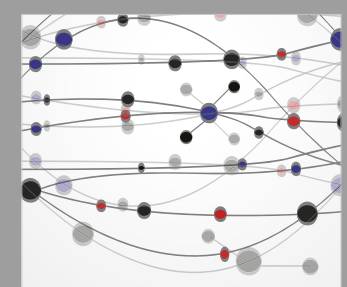

The Scientific World Journal
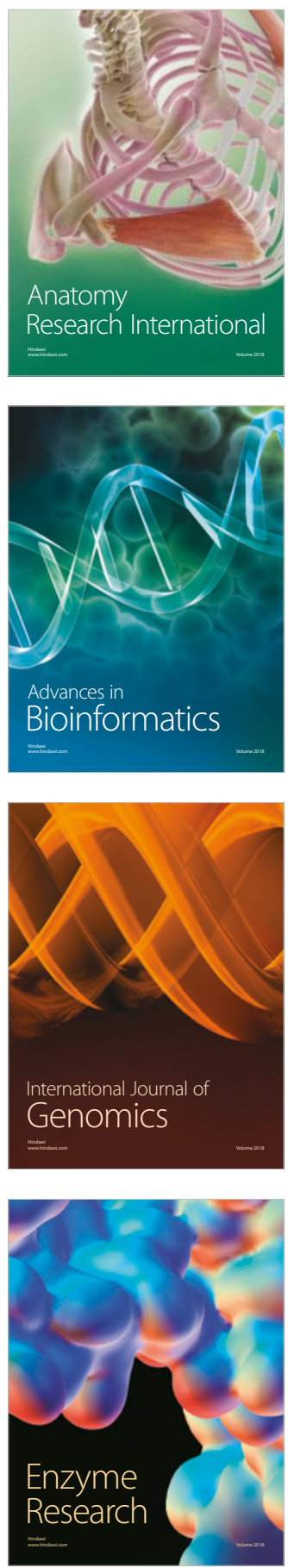
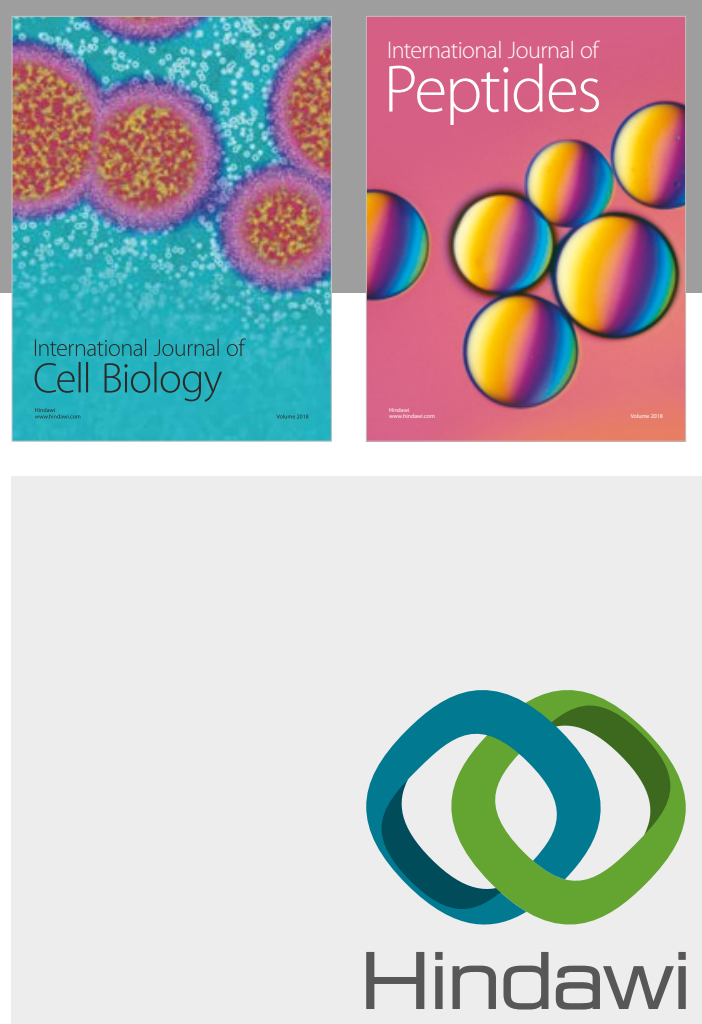

Submit your manuscripts at

www.hindawi.com
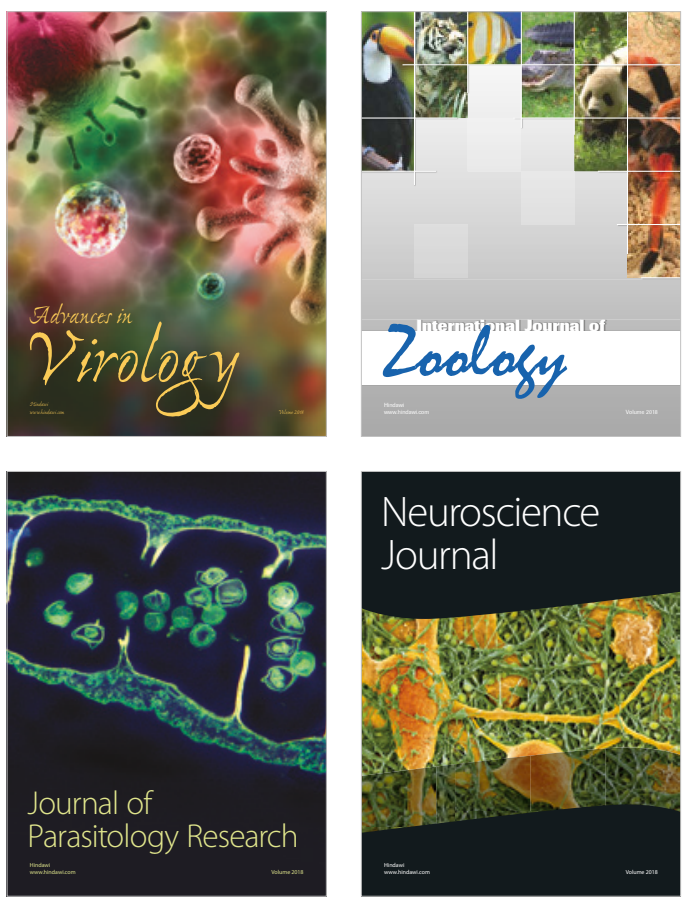
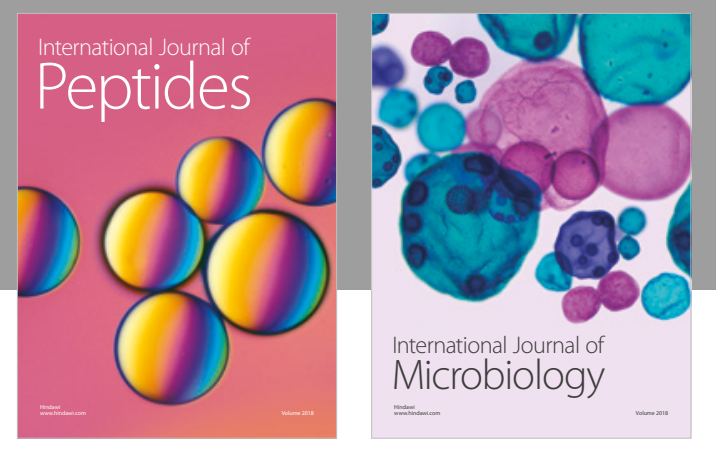

nternational Journal of Microbiology
Journal of
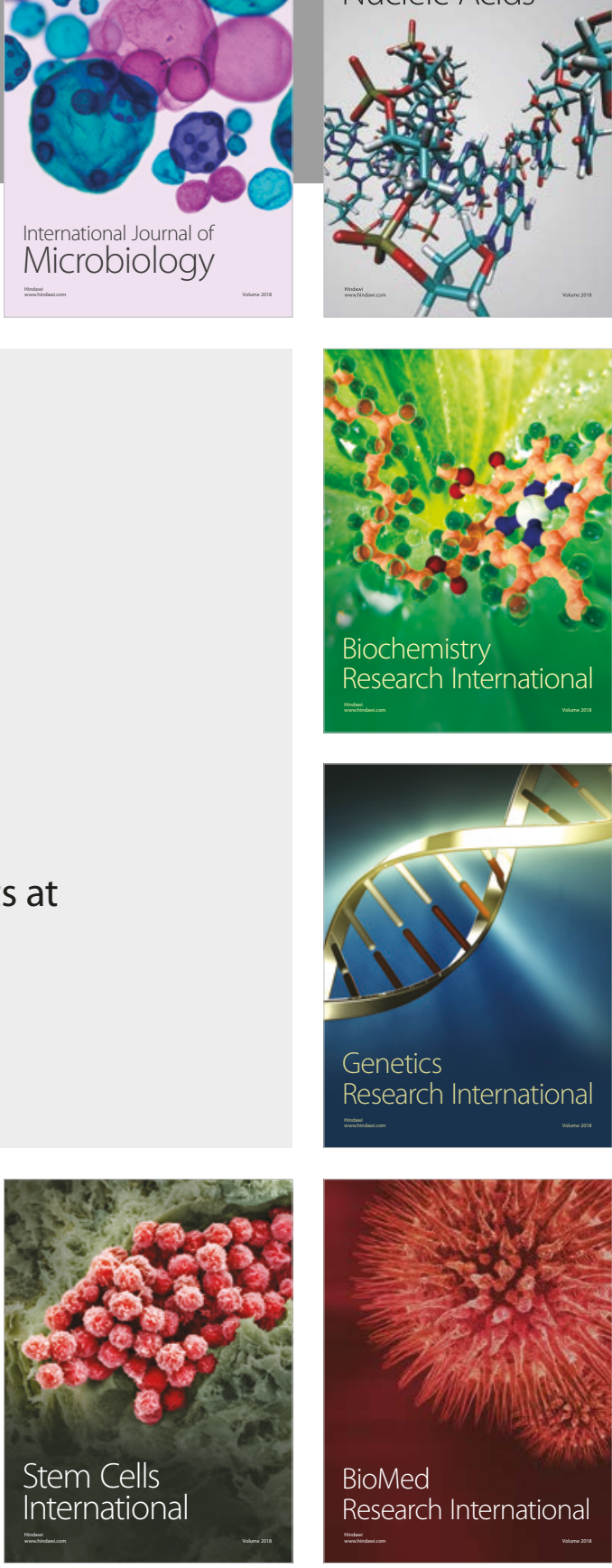
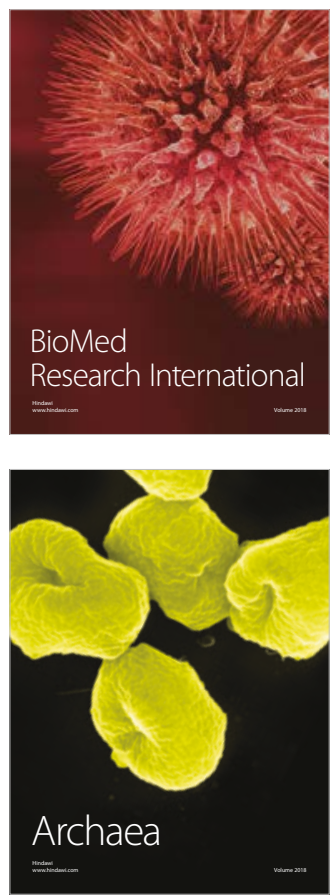